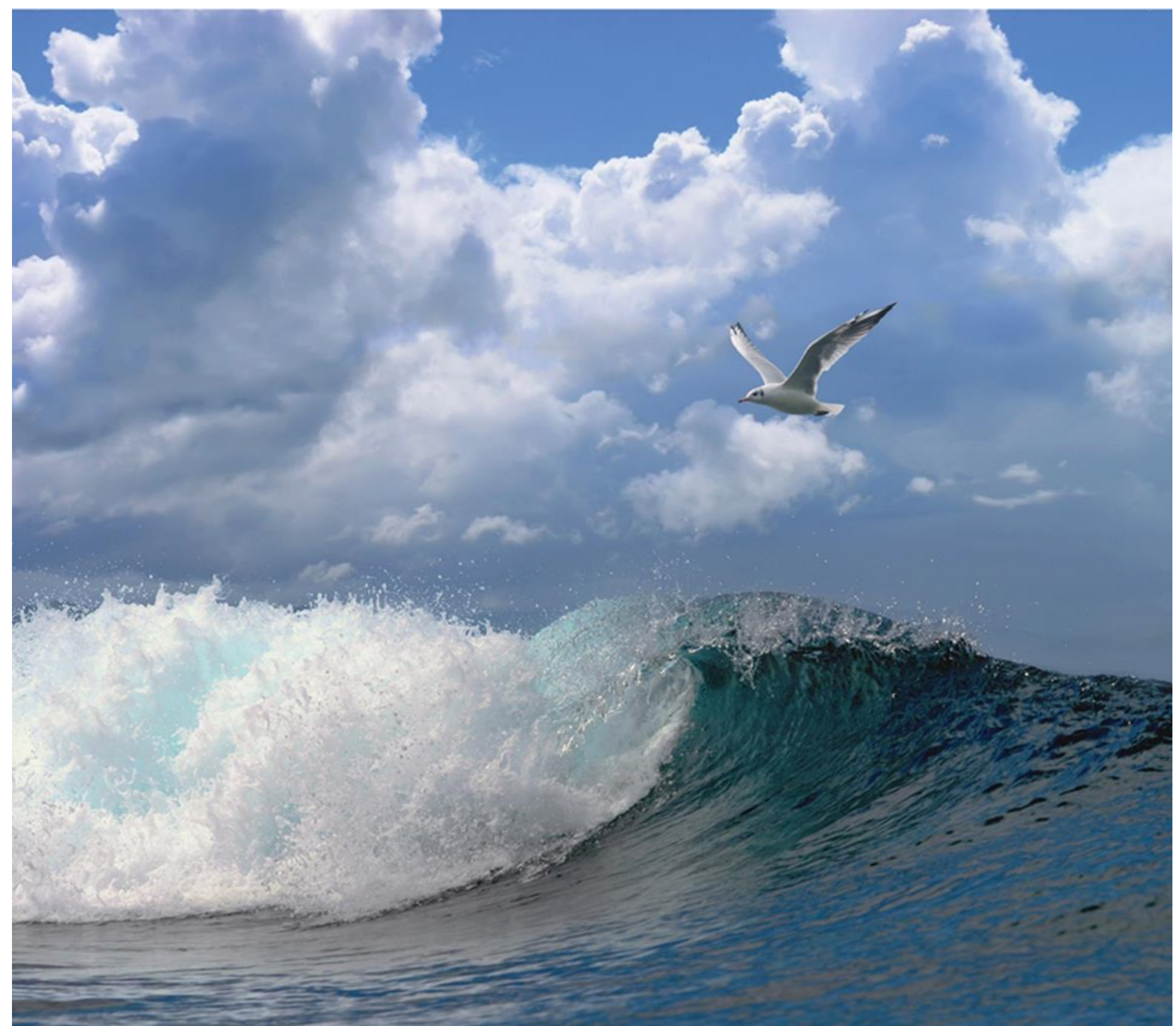

\title{
Een eerste verkenning van indices voor het bepalen van ecologische draagkracht t.b.v. zeewierkweek
}




\section{Een eerste verkenning van indices voor het bepalen van ecologische draagkracht t.b.v. zeewierkweek.}

Auteur(s): $\quad$ R.W. Nauta, R. Lansbergen, M. Poelman, L. Tonk \& H.M. Jansen

Dit onderzoek is uitgevoerd door Wageningen Marine Research in opdracht van en gefinancierd door het Ministerie van Landbouw, Natuur en Voedselkwaliteit en is onderdeel van Topsector Agri \& Food. Uitvoering geschiedt in het kader van het Maatschappelijk Innovatie Programma Seaweed (AF16202) Seaweed for food and feed (ProSeaweed, BO-59-006-001).

Wageningen Marine Research

Yerseke, April 2021

VERTROUWELIJK Nee

Wageningen Marine Research rapport C067/21 
Keywords: Seaweed, carrying capacity, sustainable production, marine resources

Dit rapport is gratis te downloaden van https://doi.org/10.18174/553613.

Wageningen Marine Research verstrekt geen gedrukte exemplaren van rapporten.

Wageningen Marine Research is ISO 9001:2015 gecertificeerd.

\section{(c) Wageningen Marine Research}

Wageningen Marine Research, instituut binnen de rechtspersoon Stichting Wageningen Research, hierbij vertegenwoordigd door Drs.ir. M.T. van Manen, directeur bedrijfsvoering

KvK nr. 09098104, WMR BTW nr. NL 8113.83.696.B16. Code BIC/SWIFT address: RABONL2U IBAN code: NL 73 RABO 0373599285
Wageningen Marine Research aanvaardt geen aansprakelijkheid voor gevolgschade, noch voor schade welke voortvloeit uit toepassingen van de resultaten van werkzaamheden of andere gegevens verkregen van Wageningen Marine Research. Opdrachtgever vrijwaart Wageningen Marine Research van aanspraken van derden in verband met deze toepassing. Alle rechten voorbehouden. Niets uit deze uitgave mag weergegeven en/of gepubliceerd worden, gefotokopieerd of op enige andere manier gebruikt worden zonder schriftelijke toestemming van de uitgever of auteur. 


\section{Inhoud}

$\begin{array}{lr}\text { Samenvatting } & 4\end{array}$

$\begin{array}{llr}1 & \text { Inleiding } & 5\end{array}$

1.1 Achtergrond $\quad 5$

1.2 Doelstelling 6

2 Draagkracht in relatie tot zeewierkweek $\quad 7$

$2.1 \quad$ Fysieke draagkracht $\quad 8$

2.2 Productiedraagkracht $\quad 9$

$\begin{array}{ll}2.3 & \text { Ecologische draagkracht } \\ \end{array}$

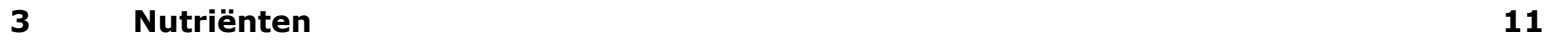

3.1 Competitie \& Seizoensdynamiek 11

3.2 Nutriëntopname \& -behoefte van zeewier 13

$\begin{array}{lll}3.3 & \text { Locatie } & 14\end{array}$

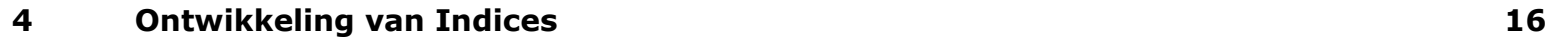

$4.1 \quad$ Potentiële indices $\quad 16$

$\begin{array}{lll}4.2 & \text { Interpretatie \& validatie } & 18\end{array}$

$5 \quad$ Rekenvoorbeeld: De Oosterschelde 19

$\begin{array}{lll}5.1 & \text { Productie draagkracht } & 21\end{array}$

$\begin{array}{lll}5.2 & \text { Indices t.b.v. ecologische draagkracht } & 23\end{array}$

6 Discussie $\quad r 24$

$\begin{array}{llr}7 & \text { Conclusie } & 26\end{array}$

$\begin{array}{llr}8 & \text { Kwaliteitsborging } & \mathbf{2 7}\end{array}$

$\begin{array}{lr}\text { Literatuur } & 28\end{array}$ 


\section{Samenvatting}

De ambities voor het gebruik van zeewier als duurzame bron van voedsel in het circulaire voedsel systeem van de toekomst is groot. Echter moet er wel realistisch gekeken worden naar de draagkracht van een gebied als de Noordzee dat vele mede gebruikers heeft. Zowel de fysieke ruimte als de ecologische draagkracht zijn in het geding bij de ambitie voor een grote zeewier productie op zee. Dit rapport maakt een eerste aanzet om mogelijke indices te identificeren om te bepalen of een beoogde productie binnen de draagkracht van een gebied valt.

Voor zeewierkweek in relatie tot de ecologische draagkracht moet er vooral gekeken worden naar de beschikbaarheid van nutriënten voor zeewier. Nutriënten zijn de basis van de voedselketen en beschikbaarheid is onderhevig aan verschillende factoren waaronder seizoensdynamiek en de aanwezigheid van (fyto-)plankton. Nutriënten komen op twee manieren in het marine systeem. Ze kunnen nieuw worden aangevoerd door rivierafvoer of de nutriënten worden geregenereerd door het lokale voedsel web zodat ze weer beschikbaar worden. Fytoplankton en zeewier zijn beide afhankelijk van nutriënten en kunnen mogelijk concurrenten zijn. De nutriëntbehoefte van zeewieren, zoals suikerwier (Saccharina latissima), is complex. Suikerwier heeft een ingebouwde interne opslag capaciteit waardoor het mogelijk is om periodes van lage nutriëntenconcentraties te overbruggen. Daarnaast is suikerwier een wintersoort die in het voorjaar haar maximale groei kent. Opname en opslag van nutriënten is hierdoor temporeel gedeeltelijk gescheiden t.o.v. de primaire productie (fytoplankton) in het voorjaar, maar kan alsnog een impact hebben doordat de totaal beschikbare hoeveelheid in het (vroege) voorjaar af kan nemen door de opname en opslag door zeewierproductie. Om inzichtelijk te krijgen of de impact van de beoogde kweek binnen de ecologische draagkracht valt worden in dit stuk twee indices gepresenteerd welke opgesteld zijn aan de hand van indices gebruikt in de schelpdiersector. Deze indices geven de mate aan waarop zeewierkweek een impact heeft op de nutriëntbeschikbaarheid van zowel de nieuw ingekomen nutriënten (e.g. rivieraanvoer) als de geregenereerde nutriënten binnen een gebied voor zeewierkweek. Dit zijn respectievelijk de New Assimilation Rate (NAR) en de Regenerated Assimilation Rate (RAR) welke gebaseerd zijn op de in de schelpdiersector gebruikte indices Clearance ratio en Grazing ratio.

Middels een rekenexercitie op basis van de Oosterschelde wordt aangetoond dat deze indices gebruikt zouden kunnen worden voor de impact van zeewierkweek op de ecologische draagkracht. Kanttekening om te maken is wel dat de berekeningen op basis van het gehele bekken gedaan worden en daarmee zeer grof zijn. Nuances moeten in acht worden genomen en verdere ruimtelijke en temporele differentiatie is nodig om verdere duiding te kunnen geven aan de ecologische draagkracht aangaande de kweek van zeewier in de Oosterschelde.

Uit de berekeningen komt naar voren dat de productie van 25ton zeewier (drooggewicht) binnen de ecologische draagkracht zou zijn (NAR $>1$; RAR $>1$ ). Echter, het gebrek aan data rondom zeewierkweek (productiehoeveelheden) en nutriëntbehoefte is substantieel. Hierdoor is het gebruik van deze indices niet volledig dekkend en behoeft verdere onderbouwing middels monitoring en dataverzameling in de omgeving van en op de zeewierboerderijen. Het monitoren van ook de omgeving is daarbij van belang doordat waterbewegingen (o.a. getijdenwerking) voor een hoge onderlinge verbinding zorgen in het gebied en er dus niet alleen een lokaal effect is, maar mogelijk ook op grotere schaal. Nutriëntbehoefte van zeewier en productiewaarden gebruikt in deze rekenexercitie zijn afkomstig uit literatuur (experimentele data) en afkomstig van experts, data aangaande nutriëntgehaltes in de waterkolom zijn afkomstig van Rijkswaterstaat (Rijkswaterstaat 2020, waterinfo). 


\section{$1 \quad$ Inleiding}

\section{$1.1 \quad$ Achtergrond}

Zeewier wordt gezien als één van de nieuwe, duurzame bronnen die moet helpen in de ontwikkeling naar een circulair en duurzaam Europa. Deze reputatie heeft zeewier verkregen doordat het naast de toepassing als humane voeding ook verschillende andere toepassingen kent zoals in de veevoederindustrie en de chemische industrie (Holdt \& Kraan 2011). In het Noordzee-akkoord is opgenomen dat in de komende decennia op circa $25 \%$ van het Nederlandse deel van de Noordzee windparken geplaatst zullen gaan worden (OFL 2020). Voor deze nieuw te ontwikkelen windparken is vastgelegd dat er meervoudig ruimtegebruik moet plaatsvinden. Dit medegebruik kan middels aangepaste vormen van visserij en maricultuur, waaronder dus ook de productie van zeewier.

Het is dan ook de wens van de overheid om zeewierproductie te ontwikkelen op de Noordzee en om dit uit te voeren is door het ministerie van Landbouw, Natuur en Voedselkwaliteit (LNV) en de Rijksdienst voor Ondernemend Nederland (RVO), binnen de topsector Agri \& Food het maatschappelijk Innovatie programma ProSeaweed opgezet. In dit programma is beoogd om wetenschappers en de sector samen te laten werken aan de ontwikkeling van duurzame zeewierkweek in Nederlandse wateren. De wens van de sector is hierbij om te komen tot een stabiele en maximale productie van zeewier, waar volgens de verwachtingen enkele tientallen tot honderden vierkante kilometers voor nodig zijn. Belangrijke vraag die hierbij gesteld wordt aan de wetenschap is hoe dit te realiseren is en wat de maximale productie is die gekweekt zou kunnen worden zonder de draagkracht van het systeem te overschrijden.

De ontwikkeling van zeewierkweek is nieuw voor Nederland en kent dus geen lange historie. Dit maakt dat verschillende zaken nog ontwikkeld moeten worden en ook dat verschillende lessen uit andere sectoren meegenomen kunnen/moeten worden. Zo brengt zeewierkweek op de Noordzee stevige risico's en grote uitdagingen met zich mee. De Noordzee is gedurende de periode van het najaar tot het voorjaar zeer onstuimig en het is juist in deze periode dat de reeds voor kweek beschikbare zeewiersoorten gekweekt worden. Deze omstandigheden leggen een grote belasting op de installatie en de gebruikte materialen nodig voor zeewierkweek. Bestaande kennis en ervaring kan daarmee een cruciale rol spelen in de ontwikkeling van de zeewiersector.

Een van de sectoren waar de zeewierkweek kennis uit kan putten is de landbouw omdat kweek op zee enigszins omschreven kan worden als boeren op zee. Zo moet een zeewierboer zijn gewas zaaien, monitoren en uiteindelijk oogsten. Om dit te doen zijn zaken nodig als mechanisatie, automatisering en gewasverbetering/-optimalisatie. Groot verschil is echter de omgeving waarin gewerkt wordt: land versus zee. Boeren op land hebben een vast gekaderde akker waar ze geen invloed hebben van ecologie/natuur dat voedselbronnen onttrekt. Bij een zeewierboerderij bevind de "akker" zich in het natuurlijk systeem en is er onderdeel van. Het is dan ook dit verschil wat misschien wel de grootste uitdagingen brengt. Ervaring en expertise uit sectoren als de visserij en off-shore kunnen juist in dit kader belangrijke technische kennis aanleveren. Het is echter van eminent belang dat deze nieuwe ontwikkeling zich duurzaam ontwikkeld. Het sleutelwoord hier is 'draagkracht', basaal uitgelegd als 'de productie die gerealiseerd kan worden zonder een onacceptabele negatieve impact op het natuurlijk systeem'. Deze productie is direct verbonden met de onttrekking van nutriënten uit zee, want waar een agrariër het land kan bemesten, kan dit op zee niet gebeuren. Hierdoor gaat de ontwikkeling van zeewier een directe concurrentie aan met het natuurlijke systeem en voedsel wat al uit zee wordt onttrokken zoals vis. Daarnaast is het een aaneengesloten systeem met sterke onderlinge verbindingen tussen gebieden waardoor een effect zich zowel lokaal als op grote afstand kan uiten (Roberts \& Upham, 2012). Met andere woorden, als je op de ene locatie zeewier gaat kweken kan dit betekenen dat er vele kilometers verder minder nutriënten zijn voor het fytoplankton om te groeien wat uiteindelijk weer de grazers en hogere trofische niveaus zou kunnen beïnvloeden.

Om deze impact in beeld te krijgen en om hier een betere inschatting van te kunnen maken is in dit rapport gekeken naar wat de mogelijke draagkracht van de Noordzee is voor zeewierkweek en hoe deze middels indices te bepalen en/of te monitoren is. 


\subsection{Doelstelling}

Om grip te krijgen op hoeveel er uit het systeem gehaald kan worden zonder een onacceptabele impact, met andere woorden hoe je binnen de draagkracht van een systeem kan blijven, worden doorgaans indicatoren en indices gebruikt. In dit rapport word een eerste aanzet gemaakt in het inzichtelijk maken en bepalen van draagkracht middels indices. In het hier gepresenteerde werk zullen we een eerste aanzet presenteren in het inzichtelijk maken van de draagkracht van ecosystemen voor de kweek van zeewier. Dit zal gedaan worden middels berekeningen die in een eerste rekenexercitie toegepast worden voor de Oosterschelde. Belangrijk gegeven hierin is dat het hierboven geschreven '(on)acceptabele impact' impliceert dat er een objectieve maat is waarin gemeten zou moeten worden. Dit stuk gaat in op de mogelijk effecten van zeewierkweek, maar zal geen beleid opstellen over wat acceptabel is. Dat is aan de overheid. WMR kan hier desgevraagd uitsluitend advies formuleren. 


\section{Draagkracht in relatie tot zeewierkweek}

Draagkracht kan in het algemeen gedefinieerd worden als de maximale populatie grootte van een soort in een ecosysteem. Of deze draagkracht duurzaam is hangt af van keuzes omtrent aanvaardbare ecologische schade of achteruitgang het systeem.

Schade kan ontstaan doordat de activiteit, in dit geval zeewierkweek, een beroep doet op de beschikbare grondstoffen in een systeem waardoor het systeem verandert. Grondstoffen zijn bijvoorbeeld nutriënten (voedingsstoffen), waterbeschikbaarheid, licht of ruimte. Hierbij behoort eveneens de mogelijke schade die kan ontstaan door restproducten, afbraak en inbreuk op processen die delicate balansen in het ecosysteem kunnen ontwrichten. Een negatief effect ontstaat wanneer de vraag aan grondstoffen hoger ligt dan de beschikbaarheid. Een dergelijke situatie zal uiteindelijk leiden tot uitputting van het systeem en een afname van de draagkracht (Figuur 1). Daarbij kan onherstelbare schade aan het gehele systeem ontstaan, bijvoorbeeld door het uitsterven van (dier)soorten.

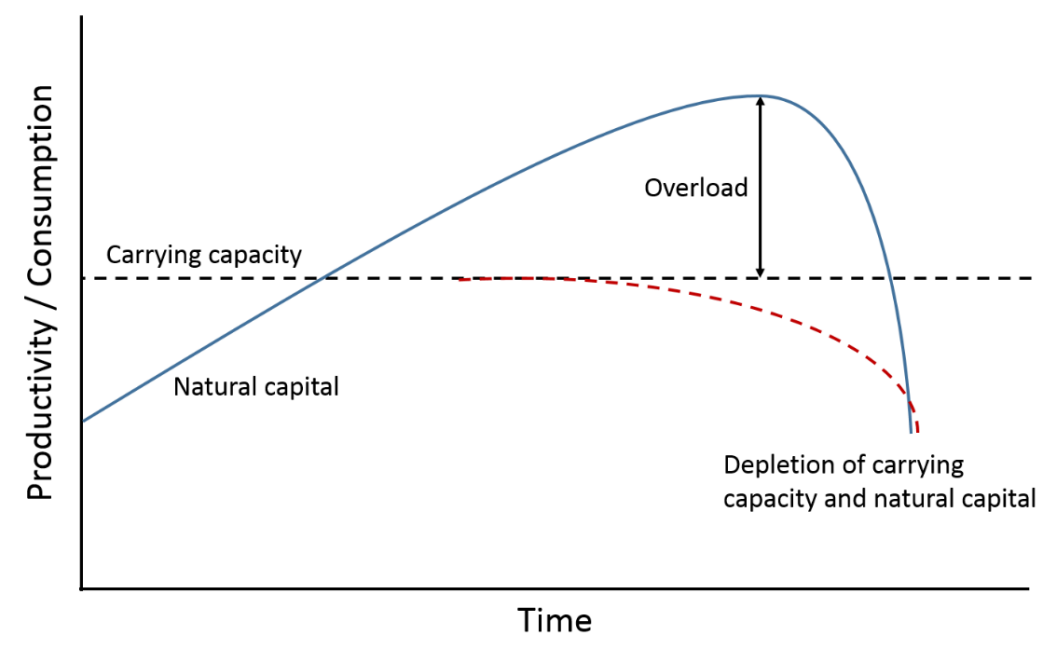

Figuur 1. Een generieke weergave van de draagkracht van een systeem. Bij langdurige overschrijding van de draagkracht zullen natuurlijke bronnen uitgeput raken en kan het systeem uiteindelijk instorten met alle gevolgen, ecologisch en economisch, van dien. (Lubsch, 2020)

De draagkracht kan bepaald worden a.d.h.v. fysieke factoren, echter kan dit ook gedaan worden op basis van productie, ecologie en sociale factoren. Dit is door Inglis et al. (2000) als volgt gedefinieerd:

1. Fysieke draagkracht; de maximale kweek bepaald op basis van fysieke ruimte en medegebruik.

2. Productiedraagkracht; de maximale productie die gerealiseerd kan worden in een bepaald gebied (NB; deze vorm houdt geen rekening met ecologische interacties) (Kaiser \& Breadman 2002)

3. Ecologische draagkracht; De maximale productie die behaald kan worden zonder (onacceptabele) impact op het ecosysteem (McKindsey et al. 2006)

4. Sociale draagkracht; De maximale maat waarin productie plaats kan vinden zonder of met acceptabele impact op recreatief, esthetisch of sociaal gebied (Gibbs 2007, Banta \& Gibbs 2009).

Een van de processen die in het perspectief van draagkracht veel aandacht verdient, en ook later in dit rapport verder toegelicht zal worden, is de beschikbaarheid aan en opname van nutriënten. Hier is door Van Duren et al. (2019) een memo over geschreven waarin een eerste aanzet is gemaakt om inzichtelijk te maken wat nu realistisch is qua omvang en grootte van zeewierkweek op de Noordzee. 
Aan deze maximale productie ligt de behoefte aan nutriënten ten grondslag welke nodig is voor zeewier om te leven en te groeien. Hierbij zijn (anorganisch) stikstof $(N)$ en fosfor $(P)$ de twee meest basale nutriënten om berekeningen en bepalingen te doen. Deze worden onttrokken uit het natuurlijk systeem, echter behoeft ook het natuurlijksysteem ook nutriënten en ontstaat er met het aanleggen van zeewierboerderijen dus een competitie tussen de wieren en het fytoplankton om deze stoffen. Wanneer de hoeveelheid wieren zodanig groot is dat alle voedingsstoffen opgenomen worden zal de maximale productie (= productie draagkracht) bereikt worden. Maar het gevolg is dat er geen voedingsstoffen meer zijn voor het fytoplankton, de basis van het mariene voedselweb. Hetgeen er toe kan leiden dat er een wezenlijke verschuiving in het Noordzee ecosysteem op kan treden met mogelijke desastreuze ecologische, maar ook economische gevolgen van dien. Het is daarom essentieel om in de ontwikkeling van zeewierkweek op de Noordzee goed in het oog te houden wat er aan nutriënten gebruikt kan worden voor kweek, om zo binnen de ecologische draagkracht van het systeem te blijven. Om hier meer inzicht in te krijgen is het dan ook nodig om eerst meer te weten over wat wieren nodig hebben en dat in relatie tot wat er in het natuurlijk systeem aanwezig is te plaatsen. De ontwikkeling van indices kunnen hierbij inzicht geven op wat de ecologische draagkracht van het systeem is voor zeewierkweek en wat er binnen deze draagkracht geproduceerd kan worden in een specifiek gebied.

\section{$2.1 \quad$ Fysieke draagkracht}

De Noordzee lijkt misschien een groot gebied vol ruimte, maar in werkelijkheid is het erg druk. Het Nederlandse deel van de Noordzee, beter bekend als het NCP (Nederlands Continentaal Plat), beslaat zo'n $10 \%$ van de totale oppervlakte en is om en nabij de $57.000 \mathrm{~km}^{2}$ groot. Hierin vinden veel activiteiten plaats en zijn specifieke gebieden toegekend aan bepaalde activiteiten, denk hierbij aan visserij, defensie oefenterrein, kabels, transportroutes en windmolenparken (Figuur 2). Er is dus een fysiek maximale draagkracht voor hoeveel vierkante kilometers aan zeewierkweek gerealiseerd zou kunnen worden. Daarnaast moet ook rekening worden houden met de diepte en bodemstructuur, dit laatste is van belang voor het verankeren van de zeewierboerderijen waarop het zeewier gekweekt gaat worden.

Door meervoudig ruimtegebruik van de windmolenparken te realiseren, ontstaat er ruimte voor onder meer zeewierkweek zonder dat daar direct ruimte voor andere doelstellingen voor ingeleverd moet worden. Momenteel is het gros van de bestaande windmolenparken nog gesloten voor medegebruik. Tot en met 2050 zijn er plannen om $14.000 \mathrm{~km}^{2}$ ( $25 \%$ van het NCP) aan windmolen gebieden te realiseren (Matthijsen et al., 2018; Boogaart et al., 2020). Wanneer de ruimte binnen de windmolenparken volledig gebruikt zou kunnen worden en we er vanuit gaan dat er geen andere locaties beschikbaar gesteld zouden worden, zou dit gezien kunnen worden als de maximale fysieke draagkracht voor de zeewierweek. Echter zijn er verschillende restricties binnen de windmolenparken die de beschikbare ruimte verminderen. Hierbij moet gedacht worden aan veiligheidszones rondom de windmolens, maar ook rondom de kabels op de zeebodem die de windmolens verbinden. Daarnaast zijn de regels wat betreft de doorvaart nog in ontwikkeling in sommige parken, maar in de meeste parken is de maximale lengte van een schip 24 meter. Op plekken waar wél gevaren mag worden kunnen geen kweeklijnen hangen wat wederom de beschikbare ruimte vermindert. Door deze beperkingen blijft er naar schatting ongeveer $25 \%$ van ruimte binnen de windmolenparken over voor medegebruik in de vorm van maricultuur. Dit alles komt neer op ongeveer 3.500 km² (Van Duren et al. 2019; Bogaart et al. 2020).

Wanneer we deze beschikbare ruimte vervolgens kwantificeren in produceerbare hoeveelheden zeewier, moeten we kijken naar de productie per oppervlakte eenheid. Van Duren et al. (2019) en experts van Wageningen Marine Research geven aan dat voor suikerwier (Saccharina latissima) een productie van $\sim 1 \mathrm{~kg}$ (drooggewicht) per vierkante meter een realistische verwachting is op de Noordzee. Dit is equivalent aan 10ton (drooggewicht) per hectare. Met een maximum van $3500 \mathrm{~km}^{2}$ aan beschikbare ruimte komt dit neer op een theoretische productie van 3,5 miljoen ton (drooggewicht) aan suikerwier. Maar let wel, dit is uitsluitend o.b.v. beschikbare ruimte, nutriëntbeschikbaarheid en alle andere factoren zijn hierbij dus buiten beschouwing gelaten. 


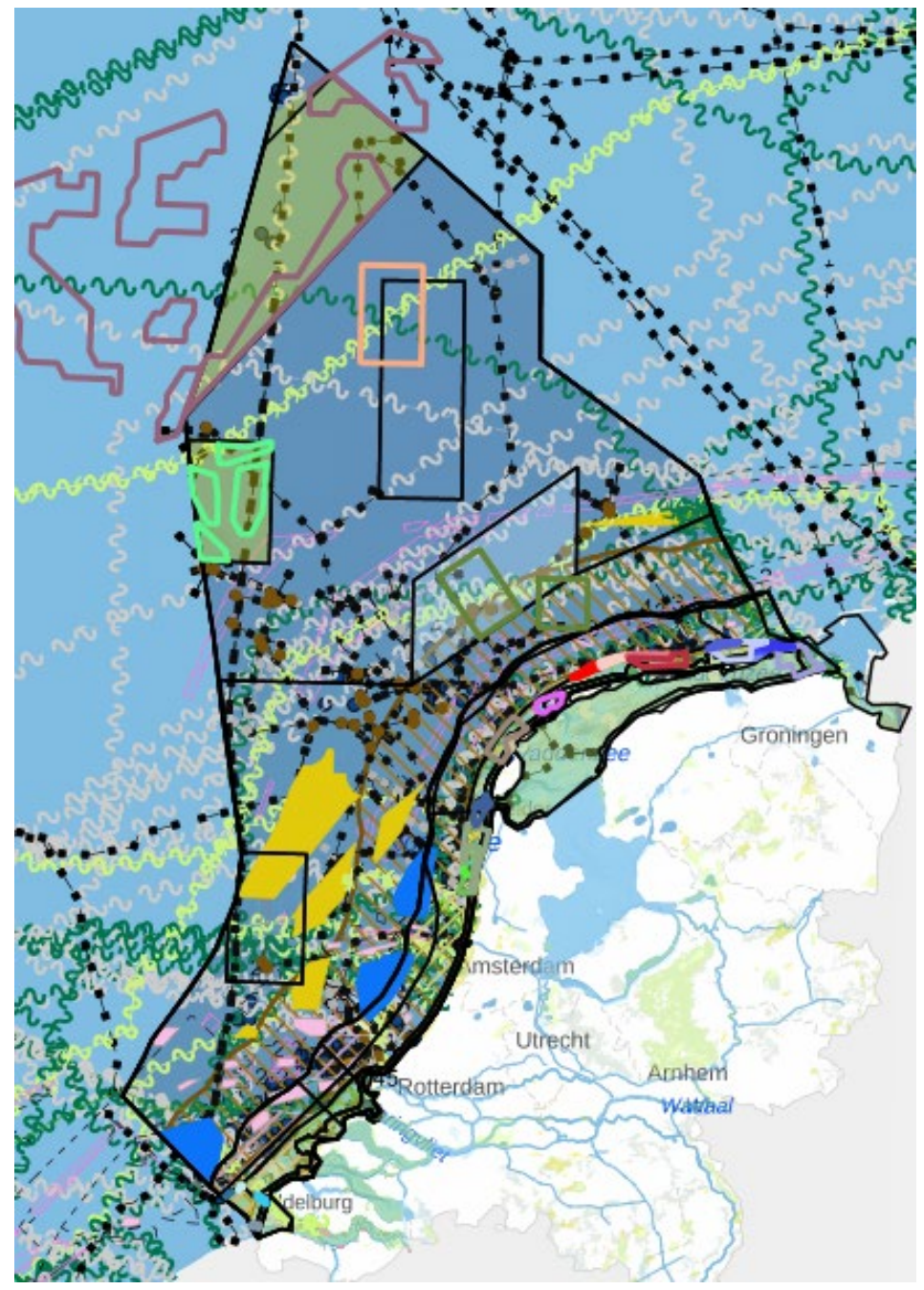

Figuur 2. Illustratief beeld van de activiteiten op de Noordzee. Hier zijn ondermeer gerealiseerde en beoogde windmolenparken weergegeven, vaarwegen, gesloten gebieden, kabels, leidingen, etc. (Noordzeeloket).

\subsection{Productiedraagkracht}

De productiedraagkracht is, zoals Inglis et al. (2000) het heeft omschreven, de maximale productie van een gebied. Hierbij wordt dus geen rekening gehouden met het milieu en het ecosysteem en reflecteert de productiedraagkracht de productie die maximaal te realiseren is in een bepaald gebied waarbij alle nutriënten opgebruikt worden. In de rekenexercitie gepresenteerd in de memo van Van Duren et al. (2019) is bepaald, op basis van een aantal zeer grove aannames, dat er een productie gerealiseerd kan worden van $2900 \mathrm{~km}^{2}$ zeewierkweek wat neerkomt op een productie van 2,9 miljoen ton suikerwier (o.b.v. 10 ton drooggewicht per ha). Deze productie is berekend op basis van alleen de nieuw inkomende nutriënten in de Noordzee. Deze 'nieuwe' nutriënten zijn om en nabij de helft van het totale hoeveelheid aanwezige nutriënten en komen voor ongeveer een kwart uit de aanvoer van de Atlantische oceaan en een kwart uit de uitstroom van rivieren.

Wanneer we vervolgens ook de overige helft aan beschikbare nutriënten meenemen, afkomstig uit de nutriëntcyclus, verdubbeld deze interne regeneratie de productie van het systeem. Dit resulteert in een productiedraagkracht van een gebied ter grootte van $5800 \mathrm{~km}^{2}$ ( $\sim 1 \%$ van het NCP). Omgerekend naar specifiek suikerwier, komt dit neer 5,8 miljoen ton (drooggewicht) per jaar. Uitsluitend kijkend naar de fysieke ruimte en productiedraagkracht kunnen we dus concluderen, zij het met een substantieel aantal grove aannames, dat de fysieke draagkracht lager is dan de mogelijke productiedraagkracht. In beide gevallen wordt geen rekening gehouden met de (mogelijke) ecologische implicaties. 


\subsection{Ecologische draagkracht}

De ecologische draagkracht houdt wel rekening met het ecosysteem, alleen is deze lastiger te bepalen dan de fysieke en/of productie draagkracht door de complexiteit van ecosystemen. Om de ecologische draagkracht te kunnen benaderen moet gekeken worden naar de plek die zeewier inneemt in het ecosysteem. In het natuurlijk systeem groeit zeewier relatief nabij de kust in vooral de litorale en sublitorale zone. Daar vormt het een habitat voor verschillende organismen waaronder weekdieren en geleedpotigen, wordt het door andere algen en epifyten gebruik als substraat en dient het in zeer beperkte mate ook al voedsel voor herbivoren. Dit zijn belangrijke diensten die zeewier levert voor zijn omgeving. Daar staat tegenover dat voor de groei en ontwikkeling zeewier, zoals eerder geschreven, nutriënten onttrekt uit zijn omgeving.

De ontwikkeling van zeewierkweek zal primair interacteren met deze twee componenten, habitatvorming en nutriënten opname. Zo zal het enerzijds een habitat gaan vormen voor diverse organismen, zoals verschillende geleedpotigen, wormen en andere benthische organismen, wat lokale biodiversiteit stimuleert (Tonk \& Jansen 2019, Jansen et al. 2019). Anderzijds zal het gekweekte wier nutriënten opnemen en daarmee dus in concurrentie zijn met het reeds aanwezige voedselweb om de beschikbare nutriënten. De mate waarin kweek, en daarmee de extractie van nutriënten, duurzaam gebeurt is tot op heden nog onbekend omdat de impact van de extractie nog niet goed bestudeerd is. Daar ligt mede aan ten grondslag dat data over groei en ontwikkeling van zeewier op de Noordzee te beperkt en/of niet beschikbaar is.

De exercitie van Van Duren et al. (2019) heeft een arbitraire grens gesteld op een onttrekking $5 \%$ van de nieuw ingekomen nutriënten in de Noordzee als een mogelijk aanvaardbaar niveau voor extractie. Deze $5 \%$ staat grofweg gelijk aan een ruimtebeslag voor zeewierkweek van $\sim 135 \mathrm{~km}^{2}$ op basis van de nutriëntbehoefte van zeewier en een productie $\sim 10$ ton/ha. Deze grens is dus zonder gedegen onderbouwing gesteld en als rekenvoorbeeld genomen door Van Duren et al. Om te komen tot een wel onderbouwde onttrekkingsgraad zal betrouwbare velddata verzameld moeten worden representatief voor de Nederlandse omstandigheden. Terugkoppeling tussen deze velddata en modelscenario's zou een betere indicatie kunnen gegeven van een grens aan nutriënten onttrekking en daarmee de ecologische draagkracht.

In de modelstudie die momenteel uitgevoerd wordt binnen het project waar dit rapport ook onderdeel van is (Vilmin \& Van Duren 2021), wordt met behulp van verschillende scenario's gekeken naar de impact die verschillende groottes van zeewierproductie kunnen hebben op onder meer nutriëntbeschikbaarheid en fytoplanktongroei. In de studie wordt ook gekeken naar wat de impact op de beschikbaarheid van stikstof én fosfor. Eerste resultaten laten zien dat er een afname is van de beschikbare nutriënten in het systeem door de opname van het zeewier. Echter, de substantiële kennisleemte op het gebied van groei en ontwikkeling van zeewier in de Noordzee is te beperkend om de modellen te valideren en/of te voorzien van afdoende input. De data gebruikt voor het model betreffen veelal labexperimenten en groeidata van elders dan de Nederlandse Noordzee.

De (ecologische) draagkracht van een systeem wordt bij andere vormen van aquacultuur reeds bepaald aan de hand van indicatoren (o.a. 'indicator species') en indices. Middels een vertaalslag kunnen deze mogelijk ook gebruikt worden voor zeewierkweek. Hier zal in hoofdstuk vier verder op ingegaan worden. 
Zeewier is, net als fytoplankton en de planten op land, een primaire producent wat maakt dat zij aan de basis van het hele voedselweb staan. Dit houdt in dat zeewier middels zonne-energie $\mathrm{CO}_{2}$ vastgelegd in suikers (fotosynthese) die gebruikt kunnen worden voor groei, ontwikkeling en voortplanting. Daarnaast hebben zeewieren, wederom net als planten en fytoplankton, voedingsstoffen nodig. Deze worden primair middels diffusie, passieve uitwisseling van stoffen door het bladoppervlak heen, door de wieren uit het milieu onttrokken en zo opgenomen in de weefsels. De meest basale voedingsstoffen die zeewier, maar ook fytoplankton, nodig heeft zijn stikstof $(N)$ en fosfor $(P)$.

In de Noordzee zien we de hoogste concentraties van deze nutriënten nabij de kust wat veroorzaakt wordt door de influx van nutriënten uit de rivieren en estuaria (Figuur 3). Echter, aan de hand van uitsluitend nutriëntconcentraties kan primaire productie (door fytoplankton en zeewier) niet worden bepaald (Harrison \& Hurd 2001). Dit komt doordat opname afhankelijk is van de balans tussen enerzijds de aanvoer middels waterbeweging, het mixen van de waterkolom of regeneratie e.d. en anderzijds de behoefte c.q. opname van nutriënten (Harrison \& Hurd 2001). Zo kan het dus zijn dat er een relatief lage concentratie nutriënten aanwezig is in een gebied, maar door bijvoorbeeld een hoge verversingsgraad er geen limitatie optreedt. Daarnaast zijn verschillende zeewieren, in tegenstelling tot fytoplankton, in staat om stikstof in de vorm van nitraat intern op te slaan (Lubsch \& Timmermans 2019). Dit maakt dat zeewier nutriënten in een periode met relatief hoge concentraties voorraden kan aanleggen om periodes van lage beschikbaarheid te overbruggen. Ook deze eigenschap speelt mee in het vraagstuk rondom ecologische draagkracht omdat deze een temporele factor in het vraagstuk inbrengt.
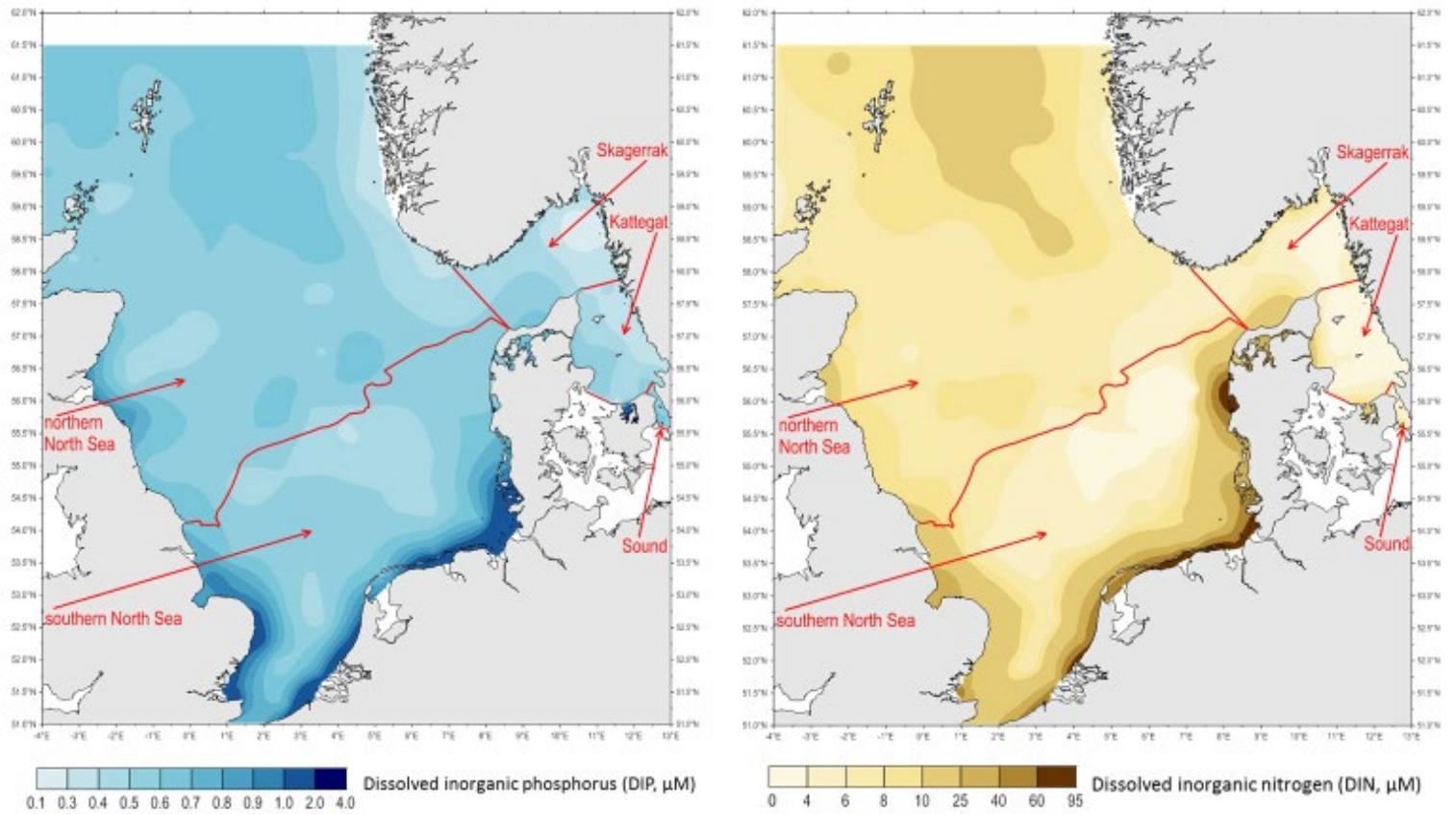

Figuur 3. [Links] Verdeling van de gemiddelde concentraties opgelost anorganisch fosfor (DIP) in de winter voor de jaren 2006-2014. [Rechts] Verdeling van de gemiddelde opgelost anorganisch stikstof (DIN) concentraties in de winterperiode voor de jaren 2006-2014. Bron: OSPAR Assessment Portal.

\subsection{Competitie \& Seizoensdynamiek}

In het mariene milieu zijn nutriënten beperkt aanwezig en speelt een concurrentiestrijd. Wanneer we ons voor nu beperken tot stikstof en fosfor, speelt deze strijd zich vooral af tussen het fytoplankton, het zeewier en de bacteriën. Wanneer er vervolgens zeewier in het systeem gebracht wordt t.b.v. kweek, gaan ook deze wieren meedingen in deze concurrentiestrijd. Voor de mariene systemen in gematigde gebieden, en daarmee de Noordzee, is daarbij de beschikbaarheid van nutriënten onderhevig aan een natuurlijke (seizoens-) dynamiek. In het vroege voorjaar neemt het 
nutriëntgehalte toe doordat er door lage temperaturen en beperkt licht nog weinig biologische activiteit is en de nutriënten van alle waterlagen gemixt worden door het onstuimige weer en de voorjaarsstormen. Wanneer de temperatuur en lichtintensiteit een bepaalde grenswaarde bereiken, ontwikkelt zich een bloei in het fytoplankton, de zogenoemde voorjaarsbloei, en daalt de nutriëntconcentratie doordat deze door het fytoplankton opgenomen wordt. Deze piek vindt over het algemeen plaats in de periode maart-april. In de loop van de voorjaarsbloei zien we ook de grazers, het zoöplankton, in aantallen toenemen gezien zij zich voeden met deze micro-algen. Na een aantal weken zien we de hoeveelheid algen afnemen, vaak veroorzaakt door het simpele feit dat het voedsel, de nutriënten, op is, maar ook door consumptie door de grazers. In de zomer stabiliseert het systeem zich door onder meer het ontstaan van gelaagdheid in waterkolom door temperatuurverschillen en variatie in zoutgehaltes, zogenaamde stratificatie. Door dit natuurkundige proces ontstaan er lagen in de waterkolom die niet of beperkt mixen waardoor de voedingsstoffen 'opgesloten' raken in diepere waterlagen en daarmee buiten bereik van de algen geraken. Ook neemt de aanvoer van nutriënten vanuit de rivieren af omdat het minder regent. Met de intrede van de herfst en het onstuimige weer wat daar mee gemoeid gaat, als ook lagere temperaturen, zien we dat deze gelaagdheid verdwijnt en nutriënten weer beschikbaar komen. Tezamen met het nog relatief warme water en afdoende zonlicht zien we vaak een tweede (beperkte) bloei ontstaan van algen totdat de winter haar intrede doet en het systeem in 'rust' gaat tot in het voorjaar de zon het systeem weer opgang brengt (Kain 1989; Lüning 1990).

Suikerwier (Saccharina latissima), de soort beoogd voor de kweek op de Noordzee, kent ook haar eigen specifieke dynamiek. De soort wordt 'gezaaid' in het najaar en geoogst in het late voorjaar (eind mei - begin juni). De soort maakt daarbij een groeispurt door in de laatste weken van de totale kweekperiode wat effectief neerkomt op de periode april t/m mei (Kain 1979; Lüning 1979; Bartsch et al. 2008, Nielsen et al. 2014). De periode van sterke groei van suikerwier overlapt dus bijna volledig met het moment van de voorjaarsbloei van fytoplankton. Dit maakt dat er dus een mogelijke directe concurrentie plaatsvindt tussen zeewier en fytoplankton voor nutriënten.

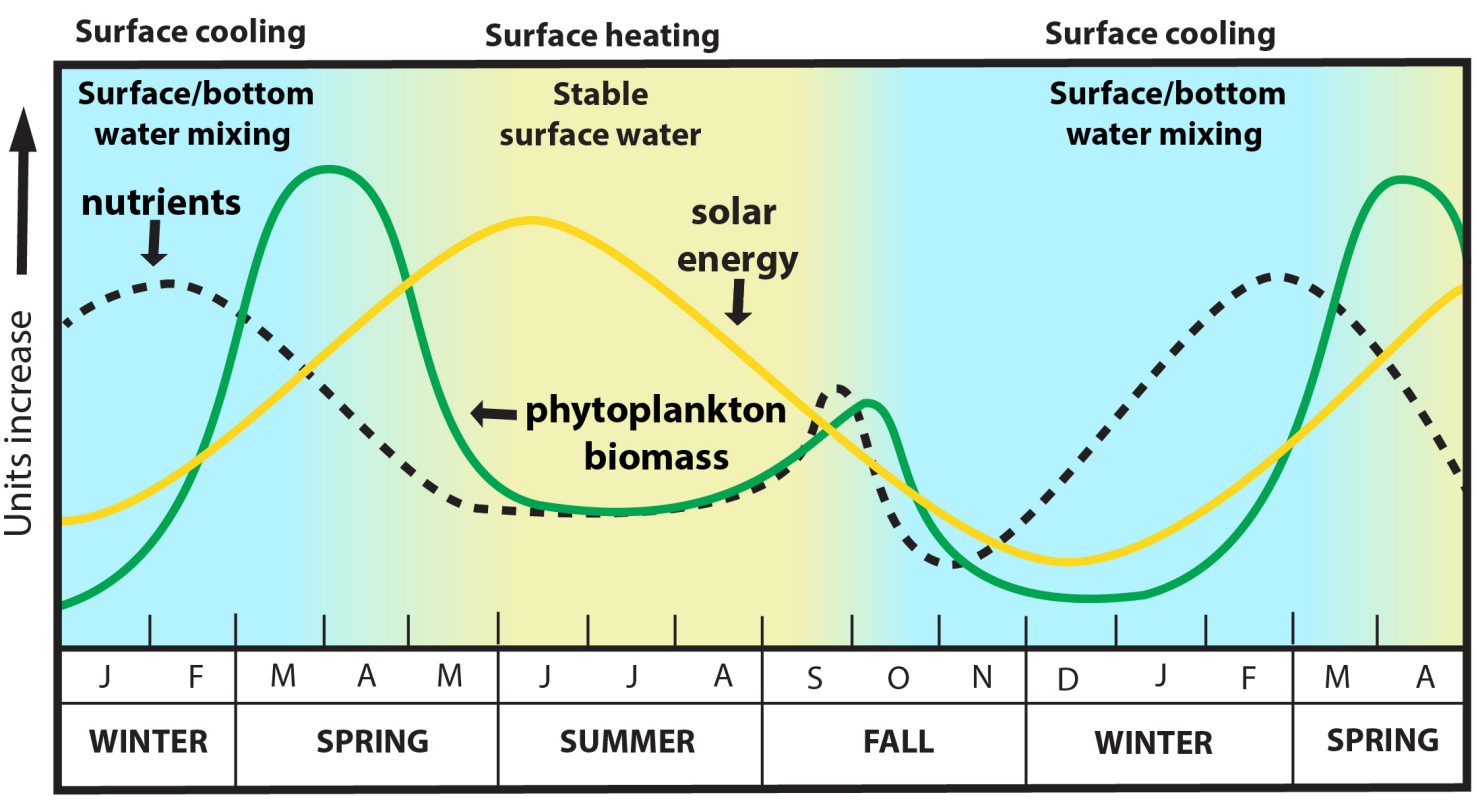

Figuur 4. Simplistische weergave van de seizoensdynamiek in de Noordzee (Ocean Data Labs, 2020).

Doordat zeewier in tegenstelling tot fytoplankton de mogelijkheid heeft om nutriënten op te slaan, de zo genoemde Internal Storage Capacity (ISC), wordt interactie en competitie tussen zeewier en fytoplankton erg complex. De wieren nemen de nutriënten op in een periode dat het fytoplankton nog niet tot bloei is gekomen. Zeewier kan op die manier de periode van april-mei, die zich kenmerkt door lage nutriëntgehaltes, toch over bruggen en zelfs een sterke groei initiëren (Chapman \& Craige 1977; Harrison \& Hurd 2001; Nielsen et al. 2014). Deze interne opslag capaciteit van zeewier maakt het mogelijk voor de wieren om tot 90 dagen zichzelf te voorzien in P-behoefte, en tot 41 dagen in $\mathrm{N}$ behoefte (tabel 1, Lubsch \& Timmermans 2019), mits de interne opslag maximaal gevuld is.

Met de realisatie van grootschalige zeewierkweek zou daarmee dus mogelijk ook een grootschalige opslag van nutriënten kunnen ontstaan. Deze opslag kan er toe leiden dat er minder nutriënten beschikbaar zijn voor de voorjaarsbloei met als resultaat een verlaagde natuurlijke biomassa aan fytoplankton en als gevolg ook minder biomassa aan grazers. Een afname in deze primaire productie van micro-algen kan ook zijn uitwerking hebben in de hogere trofische niveaus door de relatief hoge 
efficiëntie van het mariene ecosysteem. Deze trofische efficiëntie, de mate hoe effectief voedingsstoffen worden opgenomen door grazers en predatoren, ligt vele malen hoger dan op land, waardoor effecten laag in de voedselketen tot bovenaan in de keten doorwerken (Van der Meer 2020).

\subsection{Nutriëntopname \& -behoefte van zeewier}

Zeewieren hebben een interne 'voorraadkamer' of reserve waar ze nutriënten kunnen opslaan, de zogenoemde Internal Storage Capacity, ISC. De opname van nutriënten gebeurt gefaseerd en er kan onderscheid gemaakt worden in drie fases (Lubsch \& timmermans 2019, zie figuur 5 voor de eerste twee fasen):

1. De 'Surge'-opname $\left(V_{s}\right)$ geschiedt na een tijd van nutriëntlimitatie om de interne reserves aan te vullen en is daarbij losgekoppeld van groei, de opnamesnelheid neemt af naarmate de ISC gevuld raakt;

2. Wanneer het punt bereikt is dat de ISC volledig gevuld is, is er sprake van 'Maintenance'opname $\left(V_{m}\right)$ waarbij de opname uitsluitend is voor het onderhoud en ontwikkeling van het wier;

3. Als de opname beïnvloed wordt door externe factoren geldt de opnamefase 'Externally controlled'-opname $\left(V_{e}\right)$. Denk hierbij aan te weinig stroming waardoor er geen uitwisseling (diffusie) plaats kan vinden of als er simpelweg te weinig nutriënten in de omgeving zijn waardoor de wieren niet afdoende op kunnen nemen.

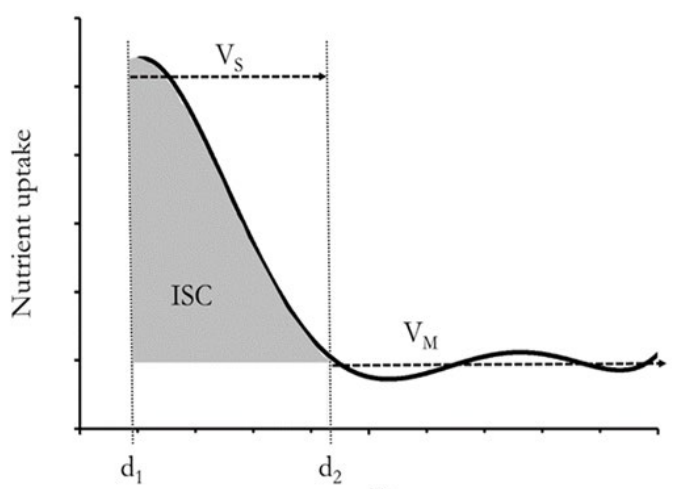

Figuur 5. Generieke weergave van de gefaseerde opname van nutriënten door zeewieren: $V_{s}=$ 'surge'opname, $V_{m}=$ 'maintenance'-opname, ISC = Internal Storage Capacity (Lubsch \& Timmermans 2018).

De opnamesnelheiden en de interne reserve capaciteit voor stikstof en fosfor wisselen sterk tussen verschillende zeewiersoorten die een potentieel hebben om gekweekt te worden in de Noordzee (tabel 1; Lubsch \& Timmermans, 2019). De extern gereguleerde opname $\left(V_{e}\right)$ is hierin niet opgenomen omdat deze, zoals de benaming reeds impliceert, gereguleerd wordt door externe factoren en dus niet een vaste waarde kent. De in tabel 1 weergegeven ratio geeft de verhouding weer tussen de opname van $P$ en $N$. Deze wisselt sterk en wijkt ook af van de Redfieldratio $(N: P=16: 1)$ die doorgaans als standaard wordt gebruikt voor fytoplankton. Zeewier en het fytoplankton verschillen in N:P ratio wat kan leiden tot een verschil in opname, wat uiteindelijk kan resulteren in een verschil in $\mathrm{N}: \mathrm{P}$ ratio in het milieu. Deze N:P ratio in het water is van belang omdat voor sommige soorten algen de opname tussen $\mathrm{N}$ en $\mathrm{P}$ gekoppeld is, zoals voor Blaaswier (Fucus vesiculosus) en Dulse (Palmaria palmata) (Perini \& Bracken 2014, Lubsch \& Timmermans 2020). In de afgelopen decennia heeft er reeds een grote verschuiving in deze ratio in kustwateren van de Noordzee plaatsgevonden door het aan banden leggen van stikstof en fosfor gebruik (Burson et al. 2016) in onder meer de landbouw en schoonmaakmiddelen. Dit heeft geleid tot een van toename in de N:P-ratio, resulterend in een P-limitatie in de kustgebieden (Radach \& Pätsch 2007, Grizzetti et al 2012, Lubsch \& Timmermans 2019). 
Tabel 1. Opname snelheden voor snelle opname en onderhoud $\left(V_{s}\right.$ en $\left.V_{m}\right)$ voor verschillende zeewiersoorten inheems voor de Noordzee en van potentiële interesse voor kweek op de Noordzee. Ook is de "internal storage capacity" (ISC) weergegeven met daarbij het aantal dagen dat deze het wier kan voorzien van nutriënten (Lubsch \& Timmermans 2019).

\begin{tabular}{|c|c|c|c|c|c|c|c|c|c|}
\hline \multirow{3}{*}{ Species } & \multicolumn{4}{|c|}{ DIP } & \multicolumn{4}{|c|}{ DIN } & Ratio \\
\hline & $\mathbf{V}_{\mathbf{s}}$ & $\mathbf{V}_{\mathbf{m}}$ & ISC & & $\mathbf{V}_{\mathbf{s}}$ & $V_{m}$ & ISC & & $\mathbf{V}_{\mathbf{m}}$ \\
\hline & $\mu \mathrm{mol} \cdot \mathrm{cm}^{-2} \cdot \mathrm{d}^{-1}$ & $\mu \mathrm{mol} \cdot \mathrm{cm}^{-2} \cdot \mathrm{d}^{-1}$ & $\mu \mathrm{mol} \cdot \mathrm{cm}^{-2}$ & dagen & $\mu \mathrm{mol} \cdot \mathrm{cm}^{-2} \cdot \mathrm{d}^{-1}$ & $\mu \mathrm{mol} \cdot \mathrm{cm}^{-2} \cdot \mathrm{d}^{-1}$ & $\mu \mathrm{mol} \cdot \mathrm{cm}^{-2}$ & dagen & DIP:DIN \\
\hline Ulva lactuca & $0.66 \pm 0.12$ & $0.07 \pm 0.04$ & $0.07 \pm 0.01$ & 10 & $12.5 \pm 5.2$ & $2.3 \pm 0.9$ & $23 \pm 7$ & 10 & $1: 32$ \\
\hline Saccharina latissima & $1.66 \pm 0.10$ & $0.30 \pm 0.09$ & $27 *$ & $90 *$ & $11.3 \pm 0.6$ & $3.9 \pm 0.7$ & $160 *$ & $41 *$ & $1: 13$ \\
\hline Laminaria digitata & $0.38 \pm 0.03$ & $0.22 \pm 0.01$ & $10 *$ & $45^{*}$ & $3.9 \pm 0.1$ & $1.8 \pm 0.4$ & $80 *$ & $44 *$ & $1: 8$ \\
\hline
\end{tabular}

*benadering gebaseerd op de $V_{m}$ (DIP:DIN) opnameratio en de fotosynthetische efficiëntie $\left(F_{v} / F_{m}\right)$ over de tijd.

\subsection{Locatie}

Op basis van draagkracht en ecologische impact is het duidelijk dat er nog een aantal grote kennisleemtes zijn alvorens gewerkt kan worden naar een duurzame zeewierkweek. Om toch een doorkijk te maken naar de haalbaarheid is het goed om te kijken naar wat de meest geschikte locaties zouden zijn in het Nederlandse deel van de Noordzee (NCP) om zeewierkweek te realiseren. Bogaart et al. $(2019,2020)$ schrijft dat de potentie voor zeewierkweek in het NCP het hoogst is in het zuidelijk deel langs de kust. Deze conclusie wordt getrokken op basis van de hogere beschikbaarheid van nutriënten, die afkomstig zijn van de rivieren. Echter, zoals ook eerder omschreven, is op basis van nutriëntgehalte niet gefundeerd vast te stellen of groei gelimiteerd wordt, en wat de maximale productie zou kunnen zijn. Stroming, waterverversing en regeneratie van nutriënten spelen zoals eerder aangegeven een belangrijke rol (Harrison \& Hurd 2001). Daarnaast is in het rapport van Bogaard et al. (2019) uitsluitend gekeken naar de geschiktheid van de verschillende (geplande) windmolenparken en niet naar het totale systeem. Dit is vervolgens uitgezet in een kansenkaart waarin de geschiktheid voor zeewierkweek aangegeven is (zie figuur 6). Twee locaties in het zuidelijk deel van de Noordzee waar actief gekeken wordt naar (de mogelijkheid voor) zeewierkweek zijn windmolenparken 'Borssele' en 'Norther'. Windmolenpark 'Borsele' is gelegen in Nederlandse wateren, tegen de Belgische grens aan (zie figuur 6) meest zuidelijke donkergroene stip). Windmolenpark 'Norther' ligt in het zelfde gebied, maar dan aan de Belgische zijde van de grens. 

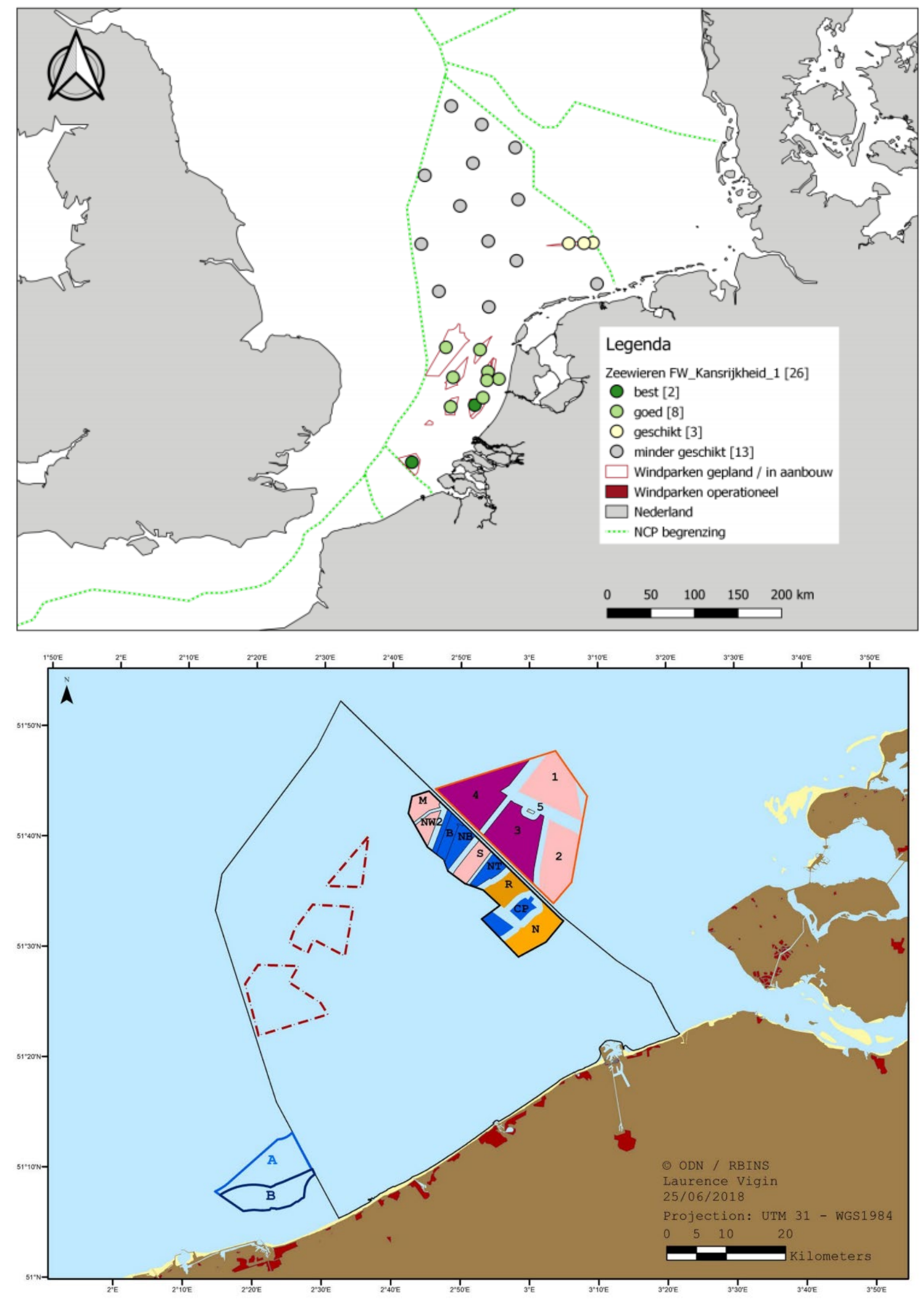

Figuur 6 [Boven] Kansenkaart voor zeewierkweek op (potentiële) offshore-windenergielocaties (uit Bogaart et al. 2019). [Onder] Geografische locaties van de windmolenparken in Nederland en België nabij de grens. De genummerde vlakken behoren tot het windpark Borsele waarbij in deel 3 van het park beoogd is om zeewierkweek te realiseren, de geletterde vlakken behoren tot de Belgische parken waarbij ' $N$ ' windpark Norther representeert (Degraer et al 2018). 


\section{$4 \quad$ Ontwikkeling van Indices}

Om de draagkracht van het systeem voor zeewierkweek te kunnen evalueren zijn er indices nodig waarmee je op een snelle en vereenvoudigde manier kan zien wat er in het systeem gebeurt. Het is daarom belangrijk om de juiste indices te formuleren die een afspiegeling zijn van het systeem. Doorgaans wordt hiervoor gekeken naar het voedsel wat een organisme opneemt, zoals gedaan wordt bij schelpdierkweek (Dame \& Prins 1998, Smaad 2017). Zeewieren zijn foto-autotroof, wat inhoudt dat zij zichzelf voorzien van voedsel middels fotosynthese waar nutriënten voor nodig zijn. Daarom kijken we voor het formuleren van indices voor de zeewierkweek naar de nutriëntenbeschikbaarheid. Echter, het is zoals eerder al aangegeven, belangrijk om niet alleen naar de nutriëntenbeschikbaarheid te kijken maar ook naar de aanvoer er van. We onderscheiden hierbij de interne regeneratie die voor nutriënten binnen een gebied en de externe aanvoer die gefaciliteerd wordt door waterverversing.

\subsection{Potentiële indices}

Het kweken van zeewier op grote schaal is voor West-Europa een nieuwe ontwikkeling. Daarom zijn er tot op heden nog geen indices ontwikkeld voor deze nieuwe sector. Zoals eerder vermeld zal er gebruik worden gemaakt van al bestaande indices uit de schelpdiersector. Ondanks het feit dat deze dieren een hoger trofisch niveau innemen in het ecosysteem, kan wel lering getrokken worden uit de ontwikkelde indices uit deze sector. Smaal (2017) heeft de indices voor schelpdieren samengevat om de draagkracht van het systeem voor schelpdier kweek inzichtelijk te maken. De door Smaal (2017) verzamelde indices voor schelpdieren zullen tegen het licht worden gehouden op hun bruikbaarheid en indien nodig of mogelijk worden aangepast voor zeewier.

Voor schelpdieren zijn er op basis van de belangrijkste factoren, voedselopname i.r.t. beschikbaarheid, twee basale en breed gebruikte indices opgesteld. De eerste van deze twee, de Clearance ratio, richt zich daarbij op het nieuwe voedsel (plankton e.d.) aangevoerd vanaf buiten het systeem (import) en geeft de verhouding tussen de filtratietijd door schelpdieren en de verblijftijd van het water. Het zegt daarmee iets over de afhankelijkheid van import op de voedselbeschikbaarheid. Wanneer de Clearance ratio $>1$ is de draagkracht van schelpdieren vooral gestuurd door de import van voedsel. Is deze $<1$ dan is de interne, lokale, voedselproductie de regulerende kracht. De tweede index, de Grazing ratio (GR), drukt de interne productie uit. Deze richt zich op de productie van voedsel binnen het ecosysteem waar de schelpdieren gekweekt worden en geeft de verhouding weer tussen de filtratietijd en de primaire productietijd. De GR moet altijd groter zijn dan 1 wanneer CLR $<1$ omdat er anders simpelweg niet afdoende tijd is voor de groei van het fytoplankton om de graasdruk van schelpdieren te compenseren.

$$
\begin{gathered}
\text { Clearance ratio }=\frac{\text { Volume } /(\text { Filtratie } * \text { Biomassa })}{\text { Verblijftijd }} \\
\text { Grazing ratio }=\frac{\text { Volume } / \text { (Filtratie } * \text { Biomassa })}{\text { Primaire productie tijd }}
\end{gathered}
$$

Aan de hand van het werk van Smaal (2017) en door nutriënten als het voedsel van zeewier te beschouwen kunnen we een vertaling maken van bovengenoemde indices voor zeewierkweek. Daarbij zijn belangrijke factoren voor zeewierkweek:

Verblijftijd

De verblijftijd van het water, de benadering voor de graad van verversing van de watermassa en daarmee de aanvoer van nieuwe nutriënten, wordt beïnvloed door stroming en tij. Dit is van invloed omdat zeewier nutriënten (het 'voedsel') uit de waterkolom moet halen waarbij de verversing van de waterkolom de concentratie en daarmee beschikbaarheid van de nutriënten beïnvloedt. Het gaat hierbij dus om de externe aanvoer van nutriënten en daarmee dus 'nieuw' zijn voor het systeem. 


\section{Interne regeneratietijd}

Hiermee wordt de tijd bedoeld die er nodig is om de nutriënten in het systeem te regenereren vanuit de afbraak en consumptie van organismen. De regeneratie van de nutriënten zorgt dat nutriënten opnieuw beschikbaar komen voor primaire producenten zoals het fytoplankton en het (te kweken) zeewier. De regeneratie wordt beïnvloed door de afbraak van organismen en organisch materiaal door grazers. Ervanuit gaande dat er een evenwichtssituatie in het systeem is en dat schelpdieren het overgrote deel vormen van de aanwezige grazers, kan de filtratie snelheid van alle scheldieren in het system een maat zijn waarmee de regeneratie tijd van het systeem kan worden benaderd. Er wordt dan wel vanuit gegaan dat remineralisatie vanuit de afbraak van dode dieren en (pseudo-)feces door bacteriën geen limiterende factor is.

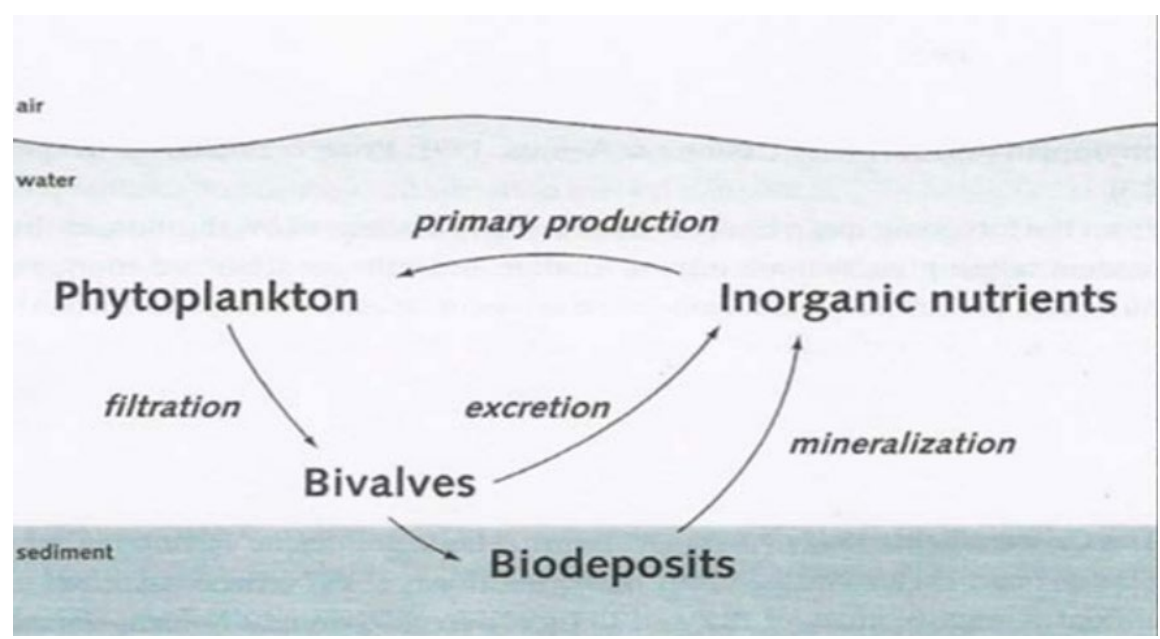

Figuur 7. Interne connectiviteit tussen nutrietenstromen (Smaal, 2017).

\section{Opname capaciteit zeewier}

De opname capaciteit van zeewier bepaald hoeveel en hoe snel zeewier nutriënten onttrekt uit het systeem. Tezamen met de hoeveelheid nutriënten die beschikbaar is en hoeveel er opgenomen wordt door de natuurlijke primaire producenten (fytoplankton en het natuurlijk zeewier) geeft dit een som waarmee gekeken kan worden in hoeverre het gekweekte zeewier concurreert met het natuurlijk systeem.

Met het in kaart brengen van deze factoren en de bestaande kennis uit de schelpdiersector is een eerste aanzet gemaakt tot vertaling en daarmee het verkrijgen van onderstaande indices voor zeewierkweek (tabel 2). 
Tabel 2. Vertaling van de factoren en indices vanuit de schelpdiersector naar zeewierkweek.

\begin{tabular}{|c|c|c|}
\hline Parameter & Vertaling voor zeewier & Calculatie \\
\hline $\begin{array}{l}\text { Primary productivity } \\
\text { (PP) }\end{array}$ & $\begin{array}{l}\text { Snelheid waarmee fotoautotrofen nutriënten, licht en } \mathrm{CO}_{2} \\
\text { omzetten in organisch materiaal. De PP geeft daarmee } \\
\text { inzicht in de opname van N,P en C. }\end{array}$ & $\begin{array}{l}\text { Metingen in } \mathrm{C} \cdot \mathrm{m}^{-3} \cdot \mathrm{dag}^{-1} \text { en doorgerekend naar } \mathrm{N} \\
\text { en } \mathrm{P} \text { o.b.v. de stoichiometrie van de beoogde } \\
\text { soort voor de kweek. }\end{array}$ \\
\hline $\begin{array}{l}\text { Internal Regeneration } \\
\text { Time (IRT) }\end{array}$ & $\begin{array}{l}\text { Tijd die het kost om de nutriëntenconcentratie te } \\
\text { vernieuwen. We nemen aan dat deze gelijk is aan de } \\
\text { filtratietijd van de alle schelpdieren in het systeem }{ }^{1} \text {. }\end{array}$ & $\begin{array}{l}\text { Filtratiecapaciteit van de grazers (filter feeders) } \\
\text { in dagen berekend middels: } \mathrm{m}^{3} * \mathrm{~m}^{-2} * \mathrm{~d}^{-1} \div \\
\text { diepte }(\mathrm{m})\end{array}$ \\
\hline Residence time (RT) & $\begin{array}{l}\text { Verblijftijd van het water als maat voor de verversingsgraad } \\
\text { (= aanvoer nieuwe nutriënten) }\end{array}$ & Getijde volume/totaal volume bij laag water \\
\hline $\begin{array}{l}\text { Nutrient Uptake rate } \\
\text { (NUR) }\end{array}$ & $\begin{array}{l}\text { De capaciteit van wieren en/of natuurlijke fotoautotrofen om } \\
\text { nutriënten op te nemen in } \mathrm{g} / \mathrm{dag}\end{array}$ & $\begin{array}{l}\text { Empirische Metingen } \\
\mu \mathrm{Mol} / \mathrm{dag} / \mathrm{g}\end{array}$ \\
\hline \multicolumn{3}{|l|}{ Indices } \\
\hline $\begin{array}{l}\text { New Assimilation Ratio } \\
\text { (NAR) }\end{array}$ & Vastlegging van de nieuwe, inkomende nutriënten & $\begin{array}{l}\text { NAR = (beschikbare nutriënten/opname van } \\
\text { nutriënten door de kweek en het natuurlijk } \\
\text { systeem(PP) )/ RT }\end{array}$ \\
\hline $\begin{array}{l}\text { Regenerated } \\
\text { Assimilation Ratio } \\
\text { (RAR) }\end{array}$ & $\begin{array}{l}\text { Vastlegging van de geregenereerde nutriënten in een } \\
\text { systeem }\end{array}$ & $\begin{array}{l}\text { RAR = (beschikbare nutriënten/opname van } \\
\text { nutriënten door de kweek en het natuurlijk } \\
\text { systeem(PP) )/ IRT }\end{array}$ \\
\hline
\end{tabular}

\subsection{Interpretatie \& validatie}

Om de voorgestelde indices goed in te kunnen zetten is een juiste interpretatie en validatie nodig. Smaal (2017) omschrijft dat de Grazing ratio (GR) óf de Clearance ratio (CLR) altijd >1 moet zijn. Dit omdat anders de voedselopname groter is dan de productie tijd (PT) en/of de aanvoer middels de verversing en het systeem snel overbelast zal raken, m.a.w. de draagkracht wordt overschreden. Veiligheidshalve wordt voor de GR of CLR tegenwoordig veelal een waarde van $>3$ aangehouden door de Aquaculture Stewardship Council (Jansen et al. 2019). Voor zeewieren kunnen de indices GR en CLR vervangen worden door respectievelijk vastlegging van inkomende (nieuwe) nutriënten (NAR) en de vastlegging van geregenereerde nutriënten (RAR). Voor deze indices geldt eveneens dat één van beiden $>1$ moet zijn om de draagkracht van het systeem m.b.t zeewierkweek niet te overschrijden. Wanneer dit niet het geval is worden er meer nutriënten uit het systeem onttrokken dan dat er geleverd kan worden vanuit externe input en/of interne regeneratie.

Het is daarom van belang om naast het hebben van indices tevens indicatoren te hebben die een reflectie geven van de staat van het systeem of deze inderdaad binnen de draagkracht geëxploiteerd wordt. Binnen de schelpdiersector worden hiervoor ondermeer het mosselvleesgewicht gebruikt als reflectie voor de conditie van de mossel en voedselcondities om de potentiële druk te indexeren. Voor zeewierkweek kan hierbij gedacht worden aan de groei en de concentraties aan inhoudsstoffen van de natuurlijke en gekweekte zeewierbiomassa (equivalent voor vleesgewicht), en nutriëntconcentraties i.c.m. primaire productie (PP) als equivalent voedselcondities. Echter, deze indicatoren zullen nog gevalideerd en getest moeten worden om de representativiteit voor draagkracht van het systeem voor zeewierkweek te kunnen kwantificeren.

\footnotetext{
${ }^{1}$ Zie paragraaf 'Interne productie tijd'
} 


\section{$5 \quad$ Rekenvoorbeeld: De Oosterschelde}

Ter illustratie en exercitie hebben we voor dit rapport een poging gedaan de indices zoals gesteld in tabel 2 te berekenen, met als casus de Oosterschelde. De Oosterschelde is gekozen omdat er momenteel veel data beschikbaar is en het een duidelijk afgebakend gebied is. De Oosterschelde bestaat uit verschillende compartimenten die door de vorm van het gebied verschillende fysische eigenschappen hebben, zoals verschillende saliniteit en verblijftijden van het water.

Volume

In deze exercitie rekenen we met een vast volume van de Oosterschelde van 2,8 miljard kuub (Wijsman, 2020).

Residence time (RT)

De verblijftijd van het water, de RT, verschilt sterk tussen de compartimenten van de Oosterschelde en is het laagst bij de monding, 25 dagen. De verblijftijd loopt verder op richting het oosten, waardoor de noord tak van de Oosterschelde een RT van 75 dagen heeft en in de "Kom" tot wel 100 dagen (Kater, Prins and van Kessel, 2003). We rekenen hier verder met de locatie nabij de monding van de Oosterschelde, het volume van dit compartiment bedraagt 1169 miljoen $\mathrm{m}^{3}$ (Wijsman, 2020). Omgerekend is de verblijftijd daar 0,068 jaar.

\section{Nutriënt concentratie}

De nutriëntgehaltes DIN en DIP variëren over de tijd en ruimte. Een meerjarig maandelijks gemiddelde van de totale stikstof en fosfaat (zuurstof gebonden fosfor) concentratie in het oppervlakte water van Lodijkse gat en Wissenkerke laat zien dat de nutriënten in de "Kom" (Lodijkse gat) van de Oosterschelde, sneller weer zal aantrekken na de voorjaarsbloei dan bij de monding (Wissenkerke) (figuur 8). De zwarte horizontale lijn geeft de minimale benodigde hoeveelheid nutriënten aan nodig voor het basis metabolisme voor S. latissima, zoals gegeven door Lubsch \& Timmermans (2019). Komen de waarden onder deze lijn dan zijn er niet afdoende nutriënten om te voldoen aan de behoefte van de
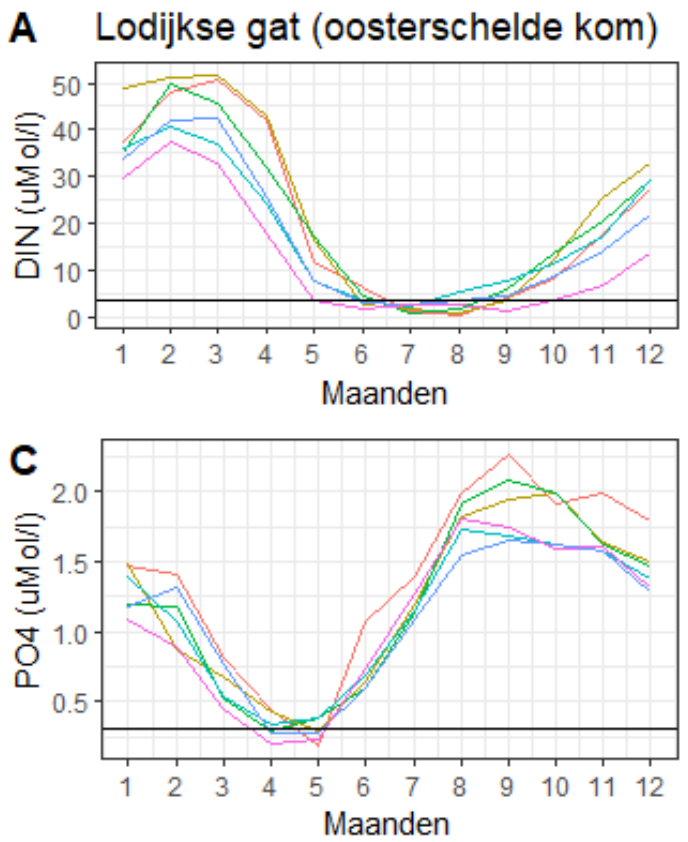

jaar_groepen

\section{B Wissenkerke (Oosterschelde mond}
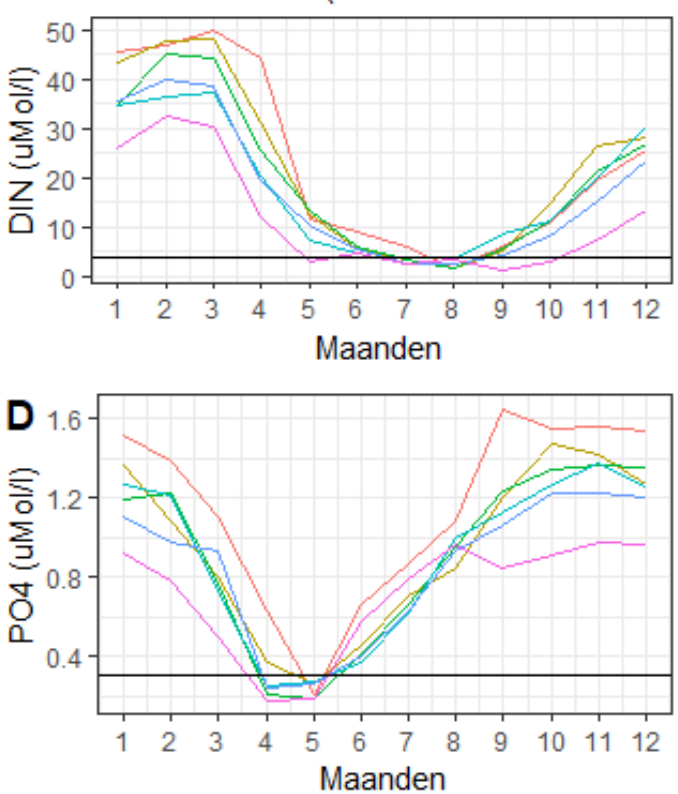

Maanden

Figuur 8. DIN en DIP $\left(\mathrm{PO}_{4}\right)$ concentraties op twee locaties in de Oosterschelde. Lodijkse gat, aan de oostzijde met een beperkte verversing maar met influx vanuit rivieren; en Wissenkerke, nabij de monding van de Oosterschelde alwaar vooral Noordzee water stroomt. De zwarte horizontale lijn geeft de minimale benodigde hoeveelheid nutriënten aan nodig voor het basis metabolisme voor S. latissima, zoals gegeven door Lubsch \& Timmermans (2019) 
wieren voor basale metabolische processen. In deze periode moeten de wieren dus een beroep doen op hun interne voorraden. Wanneer deze periode te lang duurt kan degeneratie de wieren optreden.

In deze exercitie zullen we rekenen met het wintermaximum van de nutriënten $N$ en $P$ nabij de monding omdat dit de periode is van kweek van suikerwier. Zoals geschreven is het volume van de Oosterschelde gesteld op 2,8 miljard $\mathrm{m}^{3}$ (Wijsman, 2020). De concentratie stikstof (N) in de Oosterschelde is $35 \mu \mathrm{mol} \cdot \mathrm{l}^{-1}$ (Rijkswaterstaat, 2020). Dit maakt tezamen dat de totale hoeveelheid stikstof $(N)$ in de Oosterschelde o.b.v. de winter condities vastgesteld kan worden:

$$
35 \mu \mathrm{mol} \cdot \mathrm{l}^{-1} * 2,8 \cdot 10^{12} \text { liter water }=98 \cdot 10^{6} \mathrm{~mol} \mathrm{~N}
$$

Voor fosfaat is er een concentratie (winter maximum) van $1.7 \mu \mathrm{mol} \cdot \mathrm{I}^{-1}$ in de Oosterschelde waargenomen (Rijkswaterstaat, 2020). De concentratie voor de totale hoeveelheid fosfaat (P) in de Oosterschelde (winter condities) is daarmee:

$$
1,7 \mu \mathrm{mol} * 2,8 \cdot 10^{12} \text { liter water }=4,76 \cdot 10^{6} \mathrm{~mol} P
$$

Internal Regeneration time (IRT)

Er wordt bij deze berekening van uitgegaan dat het gebied in een evenwichtssituatie verkeerd en dat er geen noemenswaardige bezinking van nutriënten is. Hierdoor is de interne regeneratie van nutriënten gelijk aan de filtratie tijd van de schelpdieren in het gebied (zie paragraaf 4.1). In de Oosterschelde vindt echter wel veel schelpdierkweek plaats waardoor er in principe nutriënten aan het gebied onttrokken worden wanneer deze worden geoogst. Dit is niet mee genomen in dit rapport.

\section{Interne productie tijd}

De interne productie tijd wordt berekend door de volume van het systeem te delen door de graasdruk van de schelpdieren per soort, waarbij een gemiddelde genomen is van de graasdruk van de jaren 2010 t/m 2015 (Jansen et al. 2019). De interne productie tijd gebruikt in deze exercitie komt uit recente literatuur van schelpdieronderzoek (Jansen et al. 2019) in de Oosterschelde en is vastgesteld op 14,6 dagen. Dit is op basis van zowel de gekweekte schelpdier soorten en de monitoring naar de wilde bestanden schelpdieren. Kater et al. (2003) gaven in eerder werk aan dat de interne productie tijd circa tien dagen is.

\section{Nutrient Uptake Rate (NUR)}

Om dit rekenvoorbeeld uit te kunnen werken moeten we een tweetal aannames doen zijnde

(1) Drooggewicht (DW) per bladoppervlak is een constante waarde van $63,7 \mathrm{~g} \cdot \mathrm{m}^{-2}$ (Jansen, unpubl. data) en (2) de productie van zeewier is $10 \mathrm{ton} \cdot \mathrm{ha}^{-1}$ drooggewicht (dit komt overeen met $1 \mathrm{~kg} \cdot \mathrm{m}^{-2}$ DW). Daarnaast zijn de volgende gegevens uit de literatuur beschikbaar (Lubsch and Timmermans, 2019):

Opname snelheid voor DIN en DIP van S. latissima per bladoppervlak.

$$
\begin{array}{ll}
\text { DIN: } & 3,9 \mu \mathrm{mol} \cdot \mathrm{cm}^{-2} \cdot \mathrm{dag}^{-1} \\
& 3,9 * 10.000=39 \mathrm{mMol} \cdot \mathrm{m}^{-2} \cdot \mathrm{dag}^{-1} \\
\text { DIP } & 0,30 \mu \mathrm{mol} \cdot \mathrm{cm}^{-2} \cdot \mathrm{dag}^{-1} \mathrm{DIP} \\
& 0,30 * 10.000=3,0 \mathrm{mMol} \cdot \mathrm{m}^{-2} \cdot \mathrm{dag}^{-1}
\end{array}
$$

Op basis van de hier bovengenoemde aannames en de gegevens uit de literatuur kan vervolgens het bladoppervlak per oppervlakte-eenheid productiegebied bepaald worden:

$$
\begin{array}{ll}
\text { Bladoppervlak per ha: } & 1000 \mathrm{~g} \div 63,7 \mathrm{~g} \cdot \mathrm{m}^{-2}=15,7 \mathrm{~m}^{2} \\
\text { Opnamesnelheid DIN: } \quad & 39 * 15,7=612 \mathrm{mmol}(\mathrm{N}) \cdot \mathrm{m}^{-2} \cdot \mathrm{dag}^{-1} \\
& 612 * 10.000=6120 \mathrm{Mol}(\mathrm{N}) \cdot \mathrm{ha}^{-1} \cdot \mathrm{dag}^{-1} \\
& \\
\text { Opnamesnelheid DIP: } \quad 3,0 * 15,7=47,1 \mathrm{mmol}(\mathrm{P}) \cdot \mathrm{m}^{-2} \cdot \mathrm{dag}^{-1} \\
& 47,1 * 10.000=471 \mathrm{Mol}(\mathrm{P}) \cdot \mathrm{ha}^{-1} \cdot \mathrm{dag}^{-1}
\end{array}
$$

Er wordt daarmee dus 6120 mol DIN en 471mol DIP opgenomen per hectare zeewierkweek per dag.

\section{Primaire productie}

De gemiddeld gemeten primaire productie (PP) in de Oosterschelde was $240 \mathrm{~g} \mathrm{C} \cdot \mathrm{m}^{-2} \cdot \mathrm{jaar}^{-1}$ (in Wijsman 2019 o.b.v. gegevens uit Malkin et al., 2011). Middels de Redfield-ratio, de gemiddelde ratio van koolstof(C):stikstof(N):fosfor(P) in fytoplankton, kan hieruit bepaald worden hoeveel stikstof en fosfor dit omvat. 
Redfield-ratio $(\mathrm{C}: \mathrm{N}: \mathrm{P})=106: 16: 1$

$\mathrm{PP}=240$ gram koolstof $\mathrm{m}^{-2}$ jaar $^{-1}$

Moleculaire massa van koolstof $=12,01 \mathrm{~g} \cdot \mathrm{mol}^{-1}$

$240 \mathrm{gC} \mathrm{m}^{-2}$ jaar $^{-1} \div 12,01 \mathrm{~g} \cdot \mathrm{mol}^{-1}=19,98 \mathrm{mo} / \mathrm{C} \mathrm{m}^{-2} \mathrm{jaar}^{-1}$

Voor stikstof:

$C: N=106 \div 16=6,625$

$19,98 \div 6,625=3,02 \mathrm{~mol} \mathrm{~N} \mathrm{~m}^{-2} \mathrm{jaar}^{-1}$

$3,02 \div 365=8,27 \mathrm{mmol} \mathrm{N} \mathrm{m}^{-2} \mathrm{dag}^{-1}$

Voor fosfor:

$N: P=16: 1$

$8,27 \div 16=0,517 \mathrm{mmol}^{P} \mathrm{~m}^{-2} \mathrm{dag}^{-1}$

\subsection{Productie draagkracht}

Uit de eerdere berekening van Van Duren et al. (2019) komt naar voren dat een hectare suikerwier $6120 \mathrm{~mol} \mathrm{~N}$ per dag opneemt. Het groeiseizoen is van november tot en met mei. Wanneer we voor de berekening uitgaan van een te waterlating ('zaaien') op 1 november en dat het materiaal 31 mei wordt opgehaald, hebben we een periode van 212 dagen. Door deze twee getallen te vermenigvuldigen met elkaar $(6120 * 212)$ komen we op een waarde van $\sim 1,3 \cdot 10^{6} \mathrm{~mol} N$ wat een hectare suikerwier nodig heeft per groeiseizoen.

Voor het rekenvoorbeeld worden er een aantal aannames gedaan. Allereerst wordt uit gegaan van de periode waarin de concentratie nutriënten in de Oosterschelde het hoogste is. Dit is in de winter, er is dan in totaal $98 \cdot 10^{6} \mathrm{~mol} \mathrm{~N}$ aanwezig. Vervolgens gaan we ervan uit dat gedurende het groeiseizoen de concentratie gelijk blijft aan het wintermaximum. Daarnaast nemen we een verblijftijd van 25 dagen aan, m.a.w. de waterkolom wordt ieder 25 dagen ververst. Gedurende het groeiseizoen (212 dagen) zou dit $\sim 8,5$ maal gebeuren wat maakt dat er een totale hoeveelheid stikstof beschikbaar zou zijn van $8,5 * 98 \cdot 10^{6}=833 \cdot 10^{6} \mathrm{~mol} \mathrm{~N}$. Hiermee hebben we dus de twee essentiële waarden om de maximale productie (productie draagkracht) van de Oosterschelde voor zeewierkweek te benaderen. Dit wordt benaderd door deze waarden door elkaar te delen, wat de volgende berekening geeft:

\section{$833 \cdot 10^{6} \mathrm{~mol} \mathrm{~N} / 1,3 \cdot 10^{6} \mathrm{~mol} \mathrm{~N}=640,7$ hectare}

De berekening van de productie draagkracht is alleen gebaseerd op de externe invoer van nutriënten. Op deze manier kan er ook naar de interne productie gekeken worden. Als er dus uitgaan word van de $\sim 1,3 \cdot 10^{6} \mathrm{~mol} \mathrm{~N}$ wat een hectare suikerwier nodig heeft per groeiseizoen en van een groeiseizoen van 212 dagen en een interne productie tijd van 14,6 dagen, dan worden de nutriënten in de Oosterschelde 14,5 keer intern geregenereerd door schelpdieren (212 delen door 14,6). Door opnieuw uit te gaan van de totale hoeveelheid stikstof die beschikbaar is in de Oosterschelde $\left(98 \cdot 10^{6}\right.$ $\mathrm{mol} \mathrm{N}$ ) te vermenigvuldigen met de interne productie tijd resulteert dit in $14,5 * 98 \cdot 10^{6}=1,4 * 10^{9} \mathrm{~mol}$ $\mathrm{N}$, beschikbaar voor primaire productie. Door dit getal te delen door de nutriëntopname van 1 hectare zeewier geeft

$$
1,4 * 10^{9} \mathrm{~mol} \mathrm{~N} / 1,3 \cdot 10^{6} \mathrm{~mol} \mathrm{~N}=1093 \text { hectare }
$$

Hieruit kan dus worden afgeleid dat de interne productie van nutriënten van groter belang is dan de externe verversing, aangezien er meer geproduceerd zou kunnen worden op basis van de interne regeneratie dan met alleen de externe instroom van nutriënten, dit komt ook naar voren in het rapport van Jansen et al. (2019). Dit is dus de maximale productie die gerealiseerd zou kunnen worden in het gebied (m.a.w. de productie draagkracht, zie sectie 2.2) Let wel, zoals eerder geschreven, hierbij wordt géén rekening gehouden met de ecologische implicaties die de verwijdering van alle nutriënten voor gevolg zouden hebben (ecologische draagkracht) en gaat dus uitsluitend over de maximaal produceerbare hoeveelheid zeewier. Als alle ratio's op deze manier gebruikt en opgeteld worden om de maximale hoeveelheid kweekbare hectares te berekenen voor de nutriënten, DIN (opgeloste anorganische stikstof) en DIP (opgeloste anorganische fosfor) geeft dit het volgende overzicht: 
Tabel 3 Maximale productie capaciteit van de Oosterschelde voor suikerwier kweek, uitgaande van een wintermaximum aan nutriënten, DIN (anorganische stikstof) en DIP (anorganische fosfor) tijdens externe verversing en interne regeneratie van nutriënten.

Winter maximum DIN Winter maximum DIP

\begin{tabular}{l|ll}
\hline Externe verversing & 640 ha & 406 ha \\
Interne productie & 1093 ha & 691 ha \\
Totale max productie & $\mathbf{1 7 3 6}$ ha & $\mathbf{1 0 9 7}$ ha
\end{tabular}

Het overzicht in tabel 3 geeft weer dat in alle gevallen de interne circulatie van het gebied meer invloed heeft op de beschikbare nutriënten dan de externe invoer in de Oosterschelde. Tevens bevestigen de waarden dat er ruimte is voor zeewierkweek in de Oosterschelde. De hoeveelheid kweek is afhankelijk van de beleidsvorming in het gebied, nutriënten die worden opgenomen door zeewier zijn niet meer beschikbaar voor de groei van fytoplankton en daarmee voor de schelpdierkweek of andere organismen zoals zoöplankton en vis in het ecosysteem. In het rapport van Jansen et al. 2019 wordt aangegeven dat op basis van de afwezigheid van correlaties in graasdruk en voedsel in de schelpdiersector het onwaarschijnlijk is dat de schelpdieren de Oosterschelde overbegrazen. Dit geeft aan dat er ruimte is voor het onttrekken van een deel van de nutriënten voor zeewierkweek, zonder dat er verlies van voedsel is voor schelpdieren.

Door middel van het rekenvoorbeeld van de productiedraagkracht hebben we de maximale productie van zeewier een bepaalde orde van grootte gegeven, op basis van de maximale nutriëntconcentraties die in de winter voorkomen. Om dit in perspectief te zetten tot andere commerciële activiteiten is het goed te weten dat 1097 hectare grofweg 3,1\% van het totaal oppervlak is van de Oosterschelde. Dit is de maximale hoeveelheid dat er gekweekt kan worden aan de hand van zowel de externe input en de regeneratie binnen de Oosterschelde van het limiterende nutriënt fosfor (DIP). Er ligt, ter vergelijking, circa 2000 hectare aan schelpdierpercelen in de Oosterschelde. Aangezien het dus gaat om de maximale productie draagkracht zou een onttrekking van nutriënten doormiddel van 1097 hectare aan zeewierkweek betekenen dat er niks meer over zou zijn voor de schelpdier kweek of voor enig ander organisme in de Oosterschelde, met alle ecologische gevolgen van dien. 


\subsection{Indices t.b.v. ecologische draagkracht}

Een vervolgstap is om de bovengenoemde informatie te verwerken in de bepaling van de indices voor een bepaalde hoeveelheid te kweken biomassa aan zeewier. In de onderstaande tabel is een voorbeeld weergegeven voor een productie van 25 ton DW aan zeewier. Dit staat o.b.v. de aannames gelijk aan een productieoppervlak van 2,5 hectare. Hiervoor worden de formules gebruikt zoals weergegeven in paragraaf 4.1 .

Tabel 4. Doorberekening van de indices voor een productie van 25 ton zeewier (drooggewicht) in de Oosterschelde a.d.h.v. de voorgestelde NAR en RAR formules.

\begin{tabular}{l|lll} 
Parameter & Betekenis & Eenheid & Waarde \\
\hline Volume & & $\mathrm{L}$ & $2,8 \cdot 10^{12} \mathrm{~L}$ \\
Nutriëntconcentratie & & $\mathrm{mol} \mathrm{N} \cdot \mathrm{F}^{-1}$ & $35 \cdot 10^{-6}$ \\
NUR & Nutrient Uptake Rate & $\mathrm{Mol}(\mathrm{N}) \cdot \mathrm{ha}^{-1} \cdot \mathrm{dag}^{-1}$ & 6120 \\
Productie (biomassa) & Biomassa gekweekt zeewier & Ton droog gewicht & 25 \\
PP & Primaire productie & $\mathrm{mol} \mathrm{N} \mathrm{m}^{-2} \mathrm{dag}^{-1}$ & $8,27 \cdot 10^{-3}$ \\
Opp. OS & Oppervlakte Oosterschelde & $\mathrm{km}^{2}$ & 350 \\
RT & Residence time (verblijftijd water) & dagen & 25 \\
\hline IRT & Internal Regeneration Time & dagen & 14.6 \\
NAR-N & New Assimilation Ratio - stikstof & $\mathbf{1 , 3 5}$ \\
NAR-P & New Assimilation Ratio - fosfor & $\mathbf{1 , 0 5}$ \\
RAR-N & Regenerated Assimilation Ratio - stikstof & $\mathbf{2 , 3}$ \\
RAR-P & Regenerated Assimilation Ratio - fosfor & & $\mathbf{1 , 8}$
\end{tabular}

Voor de rekenexercitie voor de indices voor zeewierkweek op de Oosterschelde, is uit gegaan van een productie van 2,5 hectare. De indices laten zien dat deze hoeveelheid binnen de ecologische draagkracht van het systeem zou vallen aangezien alle indices groter zijn dan 1 . Wel moet hierin de kanttekening gemaakt worden dat de waarden kleiner zijn dan 3 en dit maakt dat de waarden onder de veiligheidsmarge komen die tegenwoordig aangehouden wordt in de schelpdiersector (Jansen et al. 2019). 
In de rekenexercitie laten we zien hoe de berekening zou kunnen werken wanneer we de New Assimilation Rate (NAR) en de Regenerated Assimilation Rate (RAR) gebruiken als indices voor de bepaling of de beoogde kweek binnen de draagkracht voor zeewierkweek ligt van een bepaald gebied. De berekening is op gedaan op basis een productie van 25 ton zeewier (drooggewicht). Dit staat grofweg gelijk aan 250 ton vers zeewier ( $10 \%$ droge stof). Met de aanname van $1 \mathrm{~kg} \mathrm{DW} \cdot \mathrm{m}^{-2}$ zou dit neerkomen op een productie gebied van 2,5 hectare. Met deze aannames zijn zowel de NAR als de RAR $>1$ voor zowel de stikstof- als de fosforbeschikbaarheid wat impliceert dat de draagkracht van het systeem voor beide nutriënten niet overschreden wordt. Echter, met de NAR $<3$ is deze lager dan de waarde die tegenwoordig aangehouden wordt voor duurzame schelpdierenkweek door de Aquaculture Stewardship Council (Jansen et al. 2019).

De hier ontwikkelde indices NAR en RAR geven een waarde voor de impact van zeewierkweek op het natuurlijk systeem. Daarnaast moeten er indicatoren ontwikkeld worden die gemonitord kunnen worden om zo 'een vinger aan de pols' te kunnen houden om te kijken of er inderdaad binnen de grenzen van de ecologische draagkracht wordt gewerkt. Ook hierin kan gekeken worden naar reeds bestaande indicatoren om deze vervolgens, mits nodig, te vertalen naar indicatoren voor zeewierkweek. Waar in de schelpdiersector gekeken wordt naar beschikbaarheid van voedsel (planktonconcentraties) en productie (vleesgewicht), zou dit vertaald kunnen worden voor zeewier door te kijken naar nutriëntgehalte als equivalent voor voedsel, en primaire productie van zowel het natuurlijk systeem als het te kweken zeewier als equivalent voor vleesgewicht. Uitdaging hierin is dat de nutriëntgehaltes sterk variëren binnen een jaar, maar ook tussen de verschillende jaren (figuur 8). In het rekenvoorbeeld wordt uitgegaan van de maximale hoeveelheid aan nutriënten in de winter. Daarnaast is de influx van nutriënten in het kustgebied van Nederland sterk beïnvloed door de aanvoer vanuit de rivieren. Dit maakt dat de nutriëntconcentraties snel veranderen, wat de indices beïnvloedt. De indices zullen dus meerder keren per jaar berekend moeten worden. Daarbij komt ook dat de primaire productie (fytoplankton) sterk afhankelijk is van deze influx vanuit de rivieren waardoor ook deze over het jaar fluctueert en meermaals over het jaar bepaald moet worden en meegenomen in de berekeningen. Desondanks zou actieve monitoring van parameters zoals nutriëntconcentratie en Chlorofyl-A een goede bijdrage kunnen geven en als indicatoren kunnen dienen voor het verkrijgen van inzicht in het effect wat zeewierkweek heeft op het mariene systeem. Ten dele wordt dit reeds gedaan, maar om de lokale omstandigheden beter in beeld te krijgen is er behoefte aan een uitgebreidere monitoring. In het bijzonder zou dit gelden voor de Noordzee waar de dichtheid aan meetpunten relatief laag is t.o.v. de beoogde kweeklocaties. Verder maakt het grote verschil tussen de kustgebieden en de verder zeewaartse gebieden het ook van belang om in en om de beoogde locaties voor zeewierkweek te gaan meten. Op deze manier krijgt men beter zicht op de lokale impact als die op het overkoepelende systeem.

De berekeningen geven ons handvatten om te kijken naar de productie mogelijkheid en draagkracht bepaling voor een bepaald gebied. Ze zijn echter nog wel onderhevig aan een substantieel aantal grove aannames, net als bij het werk van Van Duren et al. (2019) het geval is. Zoals geschreven wordt uitgegaan van een maximum aan nutriënten, maar ook voor een maximum voor de opname ervan door het zeewier. De hierboven aangegeven 250 ton versgewicht is daarmee een maximum, maar kan afwijken van de mogelijke maxima door de gestelde aannames. Nutriëntgehaltes lager dan het maximum beperken de maximale productie. Ook hogere of lagere opname door het wier beïnvloed de maximale productie. De berekening is op basis van Suikerwier, waarbij de $V_{m}$ gebruikt is als zijnde de vaste maat waarin nutriënten worden opgenomen. De surge-uptake $\left(V_{s}\right)$ is daarmee dus buiten beschouwing gelaten, als ook het feit dat andere wieren andere nutriëntbehoeftes en opnamesnelheden kennen. Naast deze gewas-eigenschappen is bij de berekening ook geen rekening gehouden met de nutriëntbehoefte van het natuurlijke systeem. De leemte op dit vlak is daarmee tekenend voor de uitdaging die er ligt om een gedegen beeld te creëren voor de potentiële productie op basis van ecologische draagkracht welke van eminent belang is voor een duurzame sector. Eén van de zaken 
waaraan in dat kader gedacht moet worden is het vraagstuk dat wanneer de wieren grote hoeveelheden van de beschikbare nutriënten voorafgaand aan de fytoplanktonbloei opnemen, er minder nutriënten beschikbaar zijn voor om de bloei te voeden. Dit kan verschillende gevolgen hebben, zo kan de veranderende concentraties leiden tot afname aan totale biomassa, maar kan ook een verschuiving in soortencompositie en soortengroepen teweeg brengen. Omdat het een belangrijk periodiek fenomeen is, is ook een groot aantal organismen verder in de voedselketen afhankelijk van deze bloei waarmee dus verandering hiervan een substantiële impact kan hebben op het volledige ecosysteem. Een andere belangrijke aanname die een substantiële impact kan hebben op de te bepalen draagkracht, is de verblijftijd van het water. In de reken-exercitie gaan we uit van 25 dagen, een waarde gangbaar voor het gebied nabij de Oosterscheldekering, achter in de Oosterscheld loopt deze op tot 100 dagen (Jiang et al. 2020). Dit resulteert in dat de indices sterk per deelgebied van de Oosterschelde kunnen variëren.

Een andere uitdaging die op kan treden bij grootschalige zeewierkweek waar hier geen rekening mee gehouden wordt, is de mogelijke lokale depletie van nutriënten. In de reken-exercitie is gekeken naar de kweek t.o.v. het totale systeem. Er is dus geen rekening gehouden met het feit dat de zeewierkweek op een gecentreerd(e) plek(ken), de boerderij(en), plaatsvindt. Depletie kan optreden doordat de wieren aan de buitenzijde eerder in contact komen met het aangevoerde water en nutriënten onttrekken, hierdoor zullen er dus richting het centrum van de boerderij en stroomafwaarts minder en minder nutriënten in het water overblijven waardoor er een lokaal te kort kan ontstaan. Er zal hier rekening mee gehouden moeten worden wanneer een boerderij ingericht wordt. Hierbij moet rekening gehouden worden met onder meer de plantdichtheid (onderlinge afstand tussen lijnen), zaaidichtheid (aantal wieren per lijn/net), de stroming c.q. verversingsgraad op de locatie en de maximale grootte van de boerderij. Indices zoals de NAR en de RAR geven geen uitsluitsel over deze lokale impact, indicatoren zouden hier een hulpmiddel in kunnen zijn. 


\section{$7 \quad$ Conclusie}

Draagkracht is een aspect van groot belang voor duurzame kweek, maar het kwantificeren en meten er van is een grote uitdaging. Mede door de relatief beperkte kennis die er is over groei en ontwikkeling van zeewier in de Nederlandse kustwateren moet het gebruik van de NAR en RAR met een substantiële mate van voorzichtigheid toegepast worden. Wel bieden de indices een indicatie of de kweek duurzaam zou kunnen gebeuren voor de totaliteit van een gebied. Ontwikkeling en het vergaren van kennis en data moet echter bijdragen aan de ontwikkeling van het beter inzichtelijk maken van de draagkracht van een specifiek gebied en de impact en daarmee het gebruik van de indices NAR en RAR. Onderbouwing van de vooraf bepaalde impact en/of draagkracht moet daarbij komen uit het verzamelen van informatie in de vorm van indicatoren. Voorgestelde indicatoren zijn daarbij nutriëntgehalte en primaire productie (fytoplankton en natuurlijke zeewier) welke gemeten zou moeten worden van het gebied als ook binnen en rondom zeewierboerderijen om mogelijke lokale depletie in beeld te krijgen. Daarnaast is een belangrijke factor de groei en ontwikkeling van het te kweken zeewier. Literatuur omschrijft verschillende productiewaarden per hectare en eerste indicaties voor kweek op de Noordzee geven dat het wier groeit, maar de mate waarin is beperkt en/of de opzet van de experimenten zijn te beperkt om een goede extrapolatie te doen van de te verwachte groei. Deze vraagstukken rondom de productie zijn mogelijk tevens ook remmende factoren voor de ontwikkeling van zeewierkweek op de Noordzee. In 2021 is beoogd om binnen het project ProSeaweed meer inzicht in deze productie te krijgen in Nederlandse wateren.

Naast de ontwikkeling van kennis over productie van zeewier en ecologische draagkracht zou ook onderzoek gedaan moeten worden naar de sociale draagkracht voor zeewierkweek. Want ontwikkeling van dit nieuwe product zou mogelijk consequenties kunnen hebben voor reeds bestaande producten, activiteiten de productie van reeds bestaande producten en industrieën. Daarbij is ook de interactie tussen nieuwe en bestaande activiteiten op de Noordzee van cruciaal belang om te komen tot een duurzaam gebruik van ons natuurlijk kapitaal. De wetenschap en het onderzoek kunnen hierin aangeven wat de interacties en mogelijke consequenties zijn. Het blijft echter altijd aan de overheid om hier een beleid voor op te stellen waarin alle belangen zorgvuldig worden afgewogen. 


\section{$8 \quad$ Kwaliteitsborging}

Wageningen Marine Research beschikt over een ISO 9001:2015 gecertificeerd kwaliteitsmanagementsysteem. Dit certificaat is geldig tot 15 december 2018. De organisatie is gecertificeerd sinds 27 februari 2001. De certificering is uitgevoerd door DNV GL. 


\section{Literatuur}

Atkinson, M. J. and Smith, S. V. 1983. 'C : N : P ratios of benthic marine', Limnology and Oceanography, 28(3): 568-574.

Banta, W. and Gibbs, M. 2009. Factors controlling the development of the aquaculture industry in New Zealand: legislative reform and social carrying capacity. Coastal Management 37: 170-196.

Bartsch, I., Wiencke, C., Bischof, K., Buchholz, C.M., Buck, B.H., Eggert, A., Feuerpfeil, P., Hanelt, D., Jacobsen, S., Karez, R., Karsten, U., Molis, M., Roleda, M.Y., Schubert, H., Schumann, R., Valentin, K., Weinberger, F. \& Wiese, J. 2008. The Genus Laminaria sensu lato: recent insight and development. Eur. J. Phycol. 43(1): 1:86.

Bogaart, L. van den., Poelman, M., Tonk, L., Neitzel, S., Wal, J.T. van der, Coolen, J.W.P., Machiels, M., Rozemeijer, M., Boois, I. de, Vergouwen, S. \& Duren, L. van, 2019. Geschiktheid zeewindparken voor maricluytuur en passieve visserij - een kwalitatieve beoordeling van geschiktheid van de windparklocaites voor voedselproductie. Wagemomgem Marine research rapport C044/19. DOI: $10.1874 / 475934$

Bogaart, L. van den, Wal, J.T. van der, Tonk, L., Bos, O., Coolen, J., Poelman, M., Verhouwen, S., Duren, L. van, Janssen, H., and Timmermans, K.R., 2020. Geschiktheid Zeewindparken Voor Maricultuur En Passieve Visserij - een kwantitatieve beoordeling van de kansrijkheid van de gebieden voor de potentiële productiviteit van een selectie aan commercieel interessante soorten. Wageningen Marine Research rapport C127/19A. DOI: 10.18174/509196.

Burson, A., Stomp, M., Akil, L., Brussaard, C.P.D. \& Huisman, J., 2016. Unbalanced reduction of nutrient loads has created an offshore gradient from phosphorus to nitrogen limitation in the North Sea. Limnol. Oceanogr. 61:869-888.

Coolen, J.W.P., Weide, B. van der, Cuperus, J., Blomberg, M., Moorsel, G.W.N.M. van, Faasse, M.A., Bos, O.G., Degraer, Lindeboom, H.J., 2020. Benthic biodiversity on old platforms, young wind farms and rocky reefs. ICES J. of Marine science, 77 (3), 1250-1265. DOI: 10.1093/icesjms/fsy092.

De Galan, S., Elskens, M., Goeyens, L., Pollentier, A., Brion, N., Baeyens, W., 2004. Spatial and temporal trends in nturient concentrations in the Belgian Continental area of the North Sea during the period 1993-2000. Est.Cos. Shelf Sci. 61: 517-528.

Dame, R.F. \& Prins, T.C., 1998. Bivalve carrying capacity in coastal exosystems. Aquat. Ecol 31: 409 421.

Degraer, S., Brabant, R., Rumes, B. \& Vigin, L. (eds). 2018. Environmental Impacts of Offshore Wind Farms in the Belgian Part of the North Sea: Assessing and Managing Effect Spheres of Influence. Brussels: Royal Belgian Institute of Natural Sciences, OD Natural Environment, Marine Ecology and Management, $136 \mathrm{p}$.

Gibbs, M. 2007. Barriers to aquaculture development in Norway and New Zealand. New Zealand Aquaculture 15: 11-12.

Grizzetti, B., Bouraoui, F. \& Aloe, A., 2012. Changes of nitrogen and phosphorus loads to Europeans seas. Global Change Biol. 18(2): 769-782.

Harrison, P.J. \& Hurd, C.L., 2001. Nutrient physiology of seaweeds: application of concepts to aquaculture. Cah. Biol. Mar. 42: 71-82.

Holdt, S.L. \& Kraan, S., 2011. Bioactive compounds in seaweed: Functional Food Applications and legislation. Journal of applied phycology, 23, 543-597. 
Inglis, G.J., Hayden, B.J. and Ross, A.H. 2000. An overview of factors affecting the carrying capacity of coastal embayments for mussel culture. NIWA, Christchurch. Client report CHCO0/69

Jansen, H., Kamermans, Pauline., Glorius, S., Van Asch, M.,. (2019) Draagkracht van de Oosterschelde en westelijke Waddenzee voor schelpdieren Draagkracht van de Oosterschelde en westelijke Waddenzee voor schelpdieren. Yerseke.

Jansen, H.M., Tonk, L., Werf, A. van der, Meer, I. van der, Tuinen, S. van, Burg, S. van der, Veen, J., Bronswijk, L. en Brouwers, E., 2019. Development of offshore seaweed cultivation: food safety, cultivation, ecology and economy. Wageningen University \& Research, report C012/19.

Jansen, unpublished data. Data collected within the GENIALG program. This project has received funding from the European Union's Horizon 2020 Framework Programme under grant agreement No 727892 .

Jiang, L., Gerkema, T., Kromkamp, J.C., Van der Wal, D., Carrasco de La Cruz, P.M., and Soetaert, K., 2020. Drivers of the spatial phytoplankton gradient in estuarine-coastal systems: generic implications of a case study in a Dutch tidal bay. Biogeosciences, 17, 4135-4152.

Kain, J.M. 1979. A view of the genus Laminaria. Oceanogr. Mar. Biol. Ann. Rev. 17:101-161.

Kain, J.M. 1989. The season in the subtidal. Br. Phycol. J. 24:303-215.

Kater, B. J., Prins, T. C. en Van Kessel, A. J. M., 2003. Veranderende draagkracht van de Oosterschelde voor kokkels. Rapportage van thema's e en 3 uit het 'Lange termijn onderzoeksprogramma voedselreservering Oosterschelde', in het kader van de tweede evaluatie van het Nederlands schelpdiervisserijbeleid. RIKZ

Lubsch, A. \& Timmermans, K.R., 2018. Uptake kinetics and storage capacity of dissolved inorganic phosphorus and corresponding N:P dynamics in Ulva lactuca (Chlorophyta). J. Phycol. 54: 215 223. DOI: $10.1111 /$ jpy.12612

Lubsch, A. and Timmermans, K. R. 2019. 'Uptake kinetics and storage capacity of dissolved inorganic phosphorus and corresponding dissolved inorganic nitrate uptake in Saccharina latissima and Laminaria digitata (Phaeophyceae)', Journal of Phycology, 55(3): 637-650. DOI: 10.1111/jpy.12844.

Lubsch, A., 2020. Fact sheet Carrying capacity. Wageningen Marine Research.

Lubsch, A. \& Timmermans, K.R., 2020. Dissolved inorganic phosphate uptake and corresponding dissolved inorganic nitrate uptake in the seaweed Palmaria palmata (Rhodophyceae): ecological and physiological aspects of nutrient availability. J. Phycol 56(5): 1184-1195. DOI: $10.1111 /$ jpy. 13018

Lüning, K. 1979. Growth strategies of three Laminaria species (Phaeophyceae) inhabiting different depth zones in the sublitoral region of Helgoland (North Sea). Mar. Ecol. Prog. Ser. 1:195-207.

Lüning, K. 1990. Seaweeds: their environment, biogeography, and ecophysiology. Wiley, New York.

Malkin, S. Y., J. C. Kromkamp en P. M. J. Herman (2011) Primary production in the Oosterschelde: an analysis of historical data, size distribution and effect of grazing pressure. NIOO-CEME, Rapport, 24 pagina's.

Matthijsen, J., Dammers, E., Elzenga, H., 2018. De toekomst van de Noordzee. De Noordzee in 2030 en 2050: een scenariostudie, Den Haag: Planbureau voor de Leefomgeving.

McKindsey, C.W., Thetmeyer, H., Landry, T. and Silvert, W. 2006. Review of recent carrying capacity models for bivalve culture and recommendations for research and management. Aquacult. 261: 451-462.

Nielsen, M.M., Krause-Jensen, D., Olesen, B., Thinggaard, R., Christensen, P.B. \& Bruhn, A. 2014. Growth dynamics of Saccharina latissima (Laminariales, Phaeophyceae) in Aarhus Bay, 
Denmark, and along the species distribution range. Mar.Biol. 161: 2011-2022. DOI: $10.1007 /$ s00227-014-2482-y

Ocean Data Labs, 2020. Rutgers University. https://datalab.marine.rutgers.edu/

OFL, 2020. Het akkoord voor de Noordzee. Den Haag.

Ospar Assessment Portal; Intermediate Assessment 2017 (HASEC17/D504). Nutrient inputs to the Greater North Sea and the Bay of Biscay and Iberian Coast. D5 - Eutrophication.

Perini, V. \& Bracken, M.E.S., 2014. Nitrogen availability limits phosphorus uptake in an intertidal macroalga. Oecologia 175: 667-676.

Radach, G. \& Pätsch, J., 2007. Variability of continental riverine freshwater and nutrient inputs into the North Sea for the years 1977-2000 and its consequences for the assessment of eutrophication. Estuaries Coasts 30: 66-81.

Rijkswaterstaat. 2020 Waterinfo. Available at: https://waterinfo.rws.nl/?\#!/nav/index/.

Roberts, T., \& Upham, P., 2012. Prospects for the use of macro-algae for fuel in Ireland and the UK: An overview of marine management issues. Mar.Pol., Vol. 36, p 1047-1053.

Smaal, A. 2017. Draagkracht voor schelpdieren definities, indices en case studies. Wageningen Marine research rapport C023/17.

Tonk, L. \& Jansen, H., 2019. Notitie: Potentiële effecten van duurzame zeewierproductie op de biodiversiteit in de Noordzee. Wageningen University \& research, rapport C013/19.

Van der Meer, J. 2020. Limits to food production from the sea. Nature Food. Vol 1, p 762-764.

Van Duren, L., Poelman, M., Jansen, H., Timmermans, K., 2019. Een realistische kijk op zeewierproductie in de Noordzee. Gezamenlijk memo vanuit Wageningen Marine Research, Deltares en Koninklijk NIOZ.

Vilmin, L. \& Van Duren, L., 2021. Modelling seaweed cultivation on the Dutch continental shelf. Report 11205769-002-ZKS-0001

Wetsteyn, L. P. M. J., Duin, R.N.M., Kromkamp, J.C., Latuhihin, M.J., Peene, J., Pouwer, A. \& Prins, T.C., 2003. Verkenning draagkracht Oosterschelde, onderzoek naar veranderingen en trends in de Oosterschelde in de periode 1990 t/m 2000. Rapport RIKZ/2003.049.

Wijsman, J. 2019. Meten van primaire productie in de Oosterschelde, Grevelingenmeer en het Veerse meer. Overzicht van methodieken en plan van aanpak voor monitoring. Wageningen Marine Research, rapport C022/19

Wijsman, J. 2020. DEMO: Dynamisch Ecosysteem Model voor de Oosterschelde. Versie 1.0 : technisch rapport INNOPRO project. https://edepot.wur.nl/513561. 


\section{Verantwoording}

Rapport C067/21

Projectnummer: 4318100321

Dit rapport is met grote zorgvuldigheid tot stand gekomen. De wetenschappelijke kwaliteit is intern getoetst door een collega-onderzoeker en het verantwoordelijk lid van het managementteam van Wageningen Marine Research

Akkoord:

Dr. Ir. K.E. van de Wolfshaar

Onderzoeker

Handtekening:

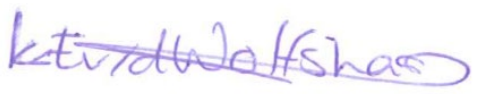

Datum:

8 september 2021

Akkoord:

Dr. Ir. T.P. Bult

Director

Handtekening:

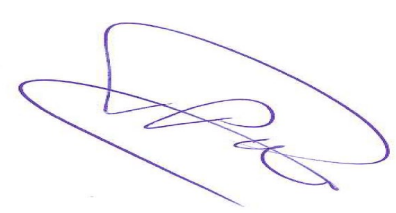

Datum:

8 september 2021 


\section{Bijlage 1 Infographic Draagkracht}

\section{Zeewierkweek en draagkracht van de Noordzee}

\section{Opschaling zeewierkweek offshore windparken en draagkracht}

Met de opkomst van offshore windparken in de Noordzee en de intentie van medegebruik van deze parken wordt aan grootschalige uitbreiding van zeewierkweek op de Noordzee gewerkt (ordegrootte van 100 tot $1000 \mathrm{~km}^{2}$ ). Maar hoeveel zeewier kan er eigenlijk op een verantwoorde manier op de Noordzee gekweekt worden? Dit is afhankelijk van de draagkracht. Draagkracht doelt op de maximale hoeveelheid zeewier die gekweekt kan worden zonder negatief effect op de beschikbare voedingsstoffen voor de groei van microalgen:

Primaire productie
toename van microalgen en
zeewier is afhankelijk van

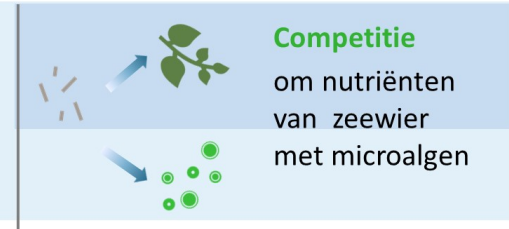

Aanvoer nutriënten in de Noordzee uit Atlantische oceaan en rivieren

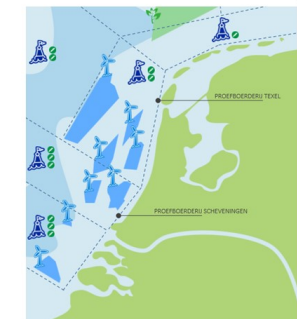

Graasdruk

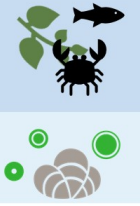
Zeewier levert voedsel voor o.a. krabben, vissen

Schelpdieren grazen op microalgen
Dieren leveren nutriënten terug aan het water.

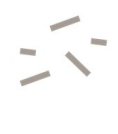

\section{Voedselweb en competitie}

Zeewier concurreert met microalgen om voedingsstoffen. Microalgen worden gegeten door schelpdieren en zoöplankton en staan daarmee aan de basis van het voedselweb. De schelpdieren worden vervolgens door grotere dieren zoals krabben, vissen en vogels gegeten. Over het algemeen geldt hoe meer microalgen, hoe meer biomassa van de hogere trofische niveaus zoals schelpdieren, krabben, vissen en vogels kan worden ondersteund.

\section{Effecten bepaling $m$.b.v. analysemodel DPSIR}

Om de effecten van een activiteit zoals zeewierkweek en de impact van die effecten op het ecosysteem te kunnen interpreteren word het DPSIR analysemodel gebruikt.

D staat voor Driving forces (sturende krachten) in dit geval zeewierkweek $\mathbf{P}$ voor Pressure (druk op het milieu) zoals verandering in beschikbare nutriënten $\mathbf{S}$ voor State (toestand van het milieu) zoals de leefomgeving voor plant en dier I voor Impact (gevolgen) bv. minder schelpdieren door overschrijding draagkracht onttrekken $\mathbf{R}$ staat voor Response (maatregelen) zoals restoratiemaatregelen.

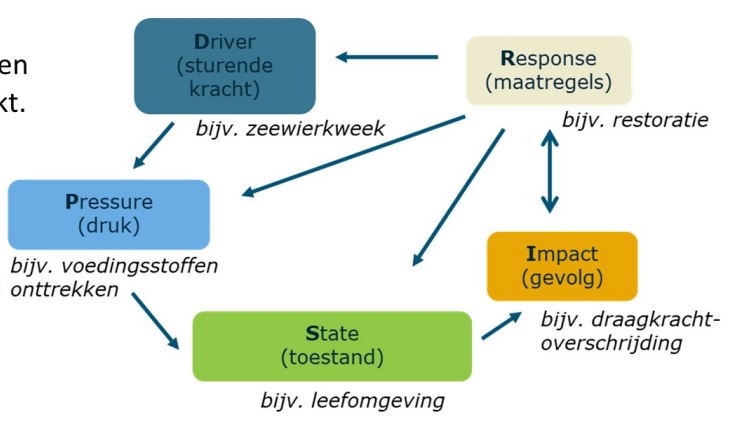

\section{Wat bepaald de druk op de draagkracht?}

Hoeveel zeewier op de Noordzee gekweekt kan worden zonder negatief effect op de draagkracht voor zowel zeewier als de andere componenten van het ecosysteem is afhankelijk van de omvang van zeewierkweek, het ecosysteem (offshore of kust) en het soort zeewier dat gekweekt wordt.

De grote vraag is dan ook hoeveel nutriënten er beschikbaar zijn voor een duurzame onttrekking door zeewier in de Noordzee? Alsmede wat is een acceptabele onttrekking van deze nutriënten?

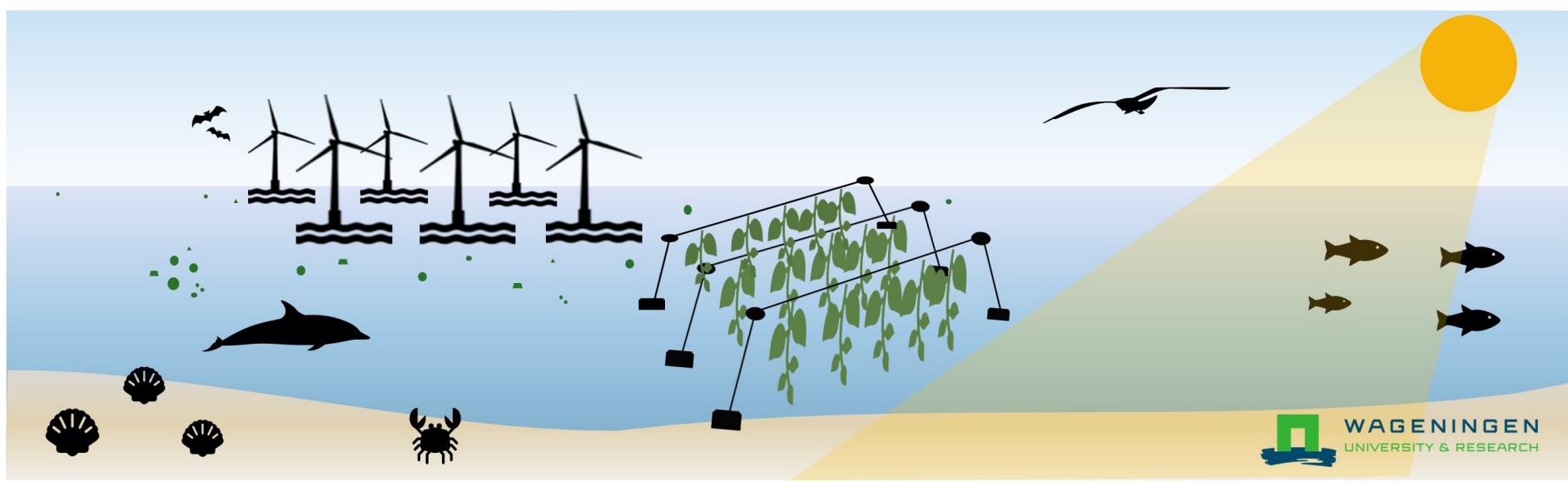


Wageningen Marine Research

T: $+31(0) 317480900$

E: marine-research@wur.nl

www.wur.nl/marine-research

Bezoekers adres:

- Ankerpark 271781 AG Den Helder

- Korringaweg 7, 4401 NT Yerseke

- Haringkade 1, 1976 CP IJmuiden
Wageningen Marine Research levert met kennis, onafhankelijk wetenschappelijk onderzoek en advies een wezenlijke bijdrage aan een duurzamer, zorgvuldiger beheer, gebruik en bescherming van de natuurlijke rijkdommen in zee-, kust- en zoetwatergebieden.
Wageningen Marine Research is onderdeel van Wageningen University \& Research. Wageningen University \& Research is het samenwerkingsverband tussen Wageningen University en Stichting Wageningen Research en heeft als missie: 'To explore the potential of nature to improve the quality of life' 